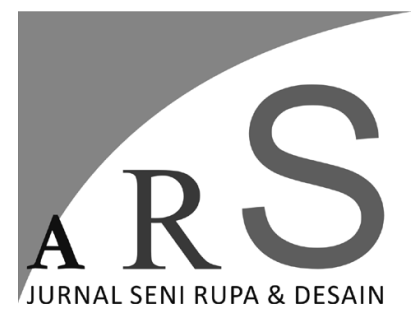

Volume 23 Nomor 3 September - Desember 2020

\title{
PENGEMBANGAN PERHIASAN UNTUK PENGRAJIN DI DESA BATAN KRAJAN KAB. MOJOKERTO JAWA TIMUR
}

\author{
Yongky Danang Prasetyo, I Nyoman Lodra, Autar Abdillah \\ Program Studi Pendidikan Seni Budaya \\ Program Pascasarjana Universitas Negeri Surabaya \\ Kampus Lidah Wetan, Jl. Lidah Wetan, Surabaya \\ Telp. (031) 7532160,E-mail: info@unesa.ac.id
}

\begin{abstract}
ABSTRAK
Penelitian ini bertujuan untuk mendeskripsikan proses pengembangan perhiasan dan mendeskripsikan kuwalitas pengembangan perhiasan motif Majapahit untuk pengrajin di Desa Batan Krajan Kab. Mojokerto Jawa Timur. Penelitian yang berpendekatan pengembangan seni kriya, ditinjau dari sudut proses dan kualitas produk perhiasan bermotif Surya Majapahit. Menggunakan metode eksperimen untuk menghasilkan produk perhiasan dengan gaya klasik dan postmodern. Metode yang digunakan dalam mengumpulkan data ialah menggunakan metode observasi untuk memperoleh data utama, serta metode wawancara dan metode analisa dokumentasi untuk memperoleh data penunjang. Hasil dari penelitian dilapangan bahwa perhiasan motif Surya Majapahit dengan kolaborasi teori ikonografi, teori ergonomi, teori design thingking dan PPE, sangat membantu pengrajin untuk dapat mengembangkan perhiasan. Mulai dari segi proses sampai kwalitas produk perhiasan yang berbahan perak. Saran yang bisa diajukan dalam penilitian ini agar bisa dimanfaatkan oleh pengrajin dalam memproses perhiasan yang berkwalitas. Sehingga untuk pengrajin lebih meningkatkan kwalitas perhiasan dalam segi desain maupun perhiasan yang bercirikan atau bermotif Majapahit. Dan bagi peneliti dapat mengkaji dan menganalisa lebih mendalam tentang perhiasan klasik maupupun postmodern bermotif Surya Majapahit lebih mendalam.
\end{abstract}

Kata Kunci: Pengembangan, perhiasan untuk pengrajin.

\begin{abstract}
Jewelry Development For Craftsmen in the village of Batan Krajan Kab. Mojokerto, East Java. This study aims to describe the process of developing jewelry and describe the quality of the development of Majapahit motif jewelry for craftsmen in Batan Krajan Village, Kab. Mojokerto East Java. Research that is near the development of craft art, viewed from the point of view of the process and quality of jewelry products with Surya Majapahit motif. Using experimental methods to produce jewelry products with classic and postmodern styles. The method used in collecting data is to use the observation method to obtain the main data, as well as the interview method and the documentation analysis method to obtain supporting data. The results of the field research show that Surya Majapahit motif jewelry with collaboration of iconographic theory, ergonomics theory, thingking design theory and PPE, really helped craftsmen to develop jewelry. Starting in terms of the process until the quality of jewelry products made from silver. Suggestions that can be submitted in this research can be used by craftsmen in processing quality jewelry. So that the craftsmen further enhance the quality of jewelry in terms of design or jewelry that is characterized by Majapahit motifs. And for researchers, it can study and analyze more deeply about classical and postmodern jewelry with the motif of Surya Majapahit in more depth.
\end{abstract}

Keywords : development, jewelery for craftsmen. 


\section{Pendahuluan}

Secara historisnya kabupaten Mojokerto tidak lepas dari nilai-nilai kebudaayan Majapahit. Sebagai kerajaan terbesar dan tersohor didunia dengan "gemah rimpah loh jinawinya" pada saat itu. Pengenalan seni dan budaya Majapahit, diharapkan mampu menggugah rasa kebanggan akan kesenian maupun ketrampilan daerah. Dari berbagai permasalahan yang ada upaya yang dilakukan untuk menjaga dan melestarikan kebudayaan Majapahit senantiasa dilakukan oleh pemerintah yaitu Dinas Perindustrian dan Perdagangan Kab. Mojokerto. Bidang yang dijadikan sebagai sasaran dalam menjaga dan melestarikan kebudayaan daerah adalah industri kreatif. Melalui bidang industri kreatif ini diharapkan generasi muda dapat mengenal dan melestarikan tradisi atau kebudayaan daerahnya, salah satunya seni kria atau kerajinan logam perhiasan.

Dengan melihat permasalahan tersebut perlu adanya penelitian dan pembuatan desain perhiasan diharapkan dapat menunjang proses produksi perhiasan dan berkompertisi di industri kreatif. Desain perhiasan dengan melihat atau menggembangkan ide dan gagasan melalui relief maupun artefak peninggalan dari kerajaan Majapahit. Dengan demikian desain perhiasan bermotif Majapahit tersebut dapat menunjang pengrajin perhiasan dalam menggembangkan gagasan dan ide kreatif untuk membentuk ciri khas perhiasan dari masing-masing pengrajin. Kontribusi dalam penelitian ini adalah sama-sama mengembangkan desain produk perhiasan berbahan perak, melainkan dalam penelitian ini mengambil tema Surya Majapahit. Surya Majapahit adalah suatu simbul atau perlambangkan peninggalan kerajaan Majapahit yang masih digunakan sebagai ikon Kab. Mojokerto. Produk perhiasan yang akan dikembangkan dalam penelitian ini yaitu cincin, gelang, anting-anting, liontin, dan bros. penelitian ini juga menggunakan depth interview dengan pengrajin perak di desa Batan krajan Kab. Mojokerto dan menggunakan beberapa teori diantanta teori pengembangan produk, teori ikonografi, dan teori ergonomi. Perbedaan dalam penelitian ini terdapat pada penekanan produk perhiasan, tidak hanya terbatas pada nilai pasar semata. Melainkan dalam segi desain dan kenyamanan produk juga perlu diperhatikan.

\section{Lingkup Penelitian}

Ruang lingkup penelitian ini mencakup beberapa hal sebagai berikut:

1. Dalam penelitian ini produk yang dikembangkan berupa desain perhiasan motif Majapahit untuk pengrajin di Desa Batan Krajan Kab. Mojokerto Jawa Timur.

2. Prosedur pengembangan desain perhiasan ini menggudagan teori Tim Brown dengan design thinking. Teori tersebut menggunakan 6 langkah dalam pengembangannya yaitu eksplorasi, identifikasi, idea, visualisasi, evaluasi, dan persuasi.

3. Produk desain perhiasan menggunakan 2 gaya dalam mengembangkannya yaitu desain gaya klasik dan desain gaya postmodern/ kontemporer.

\section{Teori dan Konsep \\ Pengembangan}

Pendapat lain diunkapkan oleh Rickey dan klein (2007) yang mendefinisikan metode penelitan dan pengembangan merupakan studi sistematis mengenai perancangan, pengembangan dan penilai dengan tujuan membangun dasar empiris untuk menciptakan sutu produk instruksional dan non instruksional, alat serta suatu model baru.

Dalam penelitian ini, peneliti mengadopsi langkah-langkah penelitian dan pengembangan model Paning, production, evaluation (PPE) menurut Richey dan Klein (2007), yaitu dengan rincian sebagai berikut:

\section{Planning (Perencanaan)}

Pada tahapan perencanaan mengurikan kegiatan perencanaan produk yang akan dibuat untuk tujuan tertentu. Pada tahapan ini peneliti menetapkan produk apa yang akan dikembangkan berdasarkan analisis kebutuhan yang dilakukan melalui penelitian dan studi literatur.

\section{Production (produksi)}

Tahapan produksi berisi kegiatan membuat produk, rancangan yang telah disusun sebelumnya dibuat menjadi sebuah produk.

3. Evaluation (Evaluasi)

Kegiatan dalam menilai produk yang dilakukan oleh ahli (expert judgment), guna mengetahui kekurangan atau kelemahan 
produk serta masukan ahli sehingga produk dapat memiliki kelayakan dan kualitas lebih baik untuk digunakan.

\section{Ikonografi}

Dalam penelitian pengembangan desain perhiasan motif Majapahit ini dilakukan dengan menggunakan teori Ikonografi dan ikonnologi Erwin Panofsky. Ikonografi adalah cabang dari sejarah seni dengan meliahat subject matter (pokok bahasan) atau makna dari karya seni (Panofsky, 1955:26). Dalam pendekatan sejarah dapat digunakan untuk memahami sebuah karya didalamnya. Ketiga tahapan ini merupakan tahapan saling berkaitan dari satu tahap ke tahap yang lainnya yang bersifat prerequisite (memiliki syarat dari satu tahap ke tahap lainnya) (Panofsky, 1955 : 32). Adapun ketiga tahapan tersebut antara lain deskripsi pra ikonografi, analisis ikonografi, dan interpretasi ikonografi dalam table (Panofsky, 1955:40). Selain ketiga tahapan tersebut, Panofsky menggunakan syarat lain yang berfungsi sebagai prinsip korektif dari setiap tahapan analisis (Burhan, 2015:3). Prinsip korektif atas interpretaasi lain (dalam table Panofsky, 1955 : 41) antara lain: pada tahapan deskripsi pra ikonografi, prinsip korektif yang digunakan ialah sejarah gaya, pada tahap analisis ikonografi, prinsip korektif yang digunakan ialah sejarah tipe, dan pada tahapan interpretasi ikonologi prinsip korektif yang digunakan ialah sejarah gejala kebudayaan.

Tahapan pertama yaitu tahapan deskripsi praikonografi dalam penelitian ini merupakan tahapan yang meneliti aspek visual pada karya seni. Tahapan ini terdiri atas makna faktual dan ekspresional, pada makna factual yang dilakukan ialah mengidentifikasi bentuk visual yang tampak pada objek serta perubahan pada adegan dan momen objek. Identifikasi dilakukan terhadap unsur-unsur visual yang tampak baik objek pokok maupun objek pendukung lainnya (Panofsky,155:28). Sedangkan ekspresional dilakukan dengan mengungkapkan empeti dari pengamatan penelitian pada kebiasaan dan rasa familiar dari objek dan adegan objeknya. Mengamati hubungan antara objek dan bentukbentuk pendukung dengan adegan peristiwanya dapat mengungkap kualitas ekspresional karakter objek dalam karya seni itu (Panofsky dalam Burhan,2015:3-4).Agar hasil deskripsipada tahap pra ikonografi tajam perlu untuk menggunakan prinsip korektif interpretasi sejarah gaya. Prinsip korektif pada tahap deskripsi pra ikonografi ini sebagai syarat yang tidak dapat dihilangkan oleh sebab itu sifatnya konfirmatif. Gaya dapat mengungkapkan kecenderungan apspek visual yang dapat dikelompokkan berdasarkan waktu, wilayah, teknik, subject matter, dan sebaginya (Zuliati, 2014 : 4).

Tahapan kedua ialah tahapan analisis ikonografi yang berusaha mengidentifikasi makna sekunder. Tahapan ini masih berhubungan dengan tahapan deskripsi pra ikonografi yaitu pada bentuk visual dan ekspresi dengan tema dan konsep. Untuk dapat melihat hubungan tersebut diperlukan pengetahuan serta pengamatan pada kebiasaan yang berangkat dari pengalaman praktis sehari-hari. Memerlukan pengetahuan serta pengetahuan pengamatan yang berangkat dari berbagai sumber lain seperti imajinasi karya seni lainnya, literature, dan berbagai alegori (Panofsky, dalam Burhan, 2015 : 4). Prinsip korektif yang digunakan dalam tahapan analisis ikonografi ialah pada interpretasi sejarah tipe. Sejarah tipe merupakan beragam kondisi sejarah, objek, serta peristiwa yang tervisualkan memalui bentuk. Dengan memahami sejarah tipe dapat menambah maupun mengkoreksi pengetahuan berdasrkan sumber literature yang terdiri dari beragam kondisi sejarah, tema, maupun konsep khusus ternyatakan lewat objek dan bentuk (Panofsky, 1955 : 37).

Tahapan terakhir adalah pada tahapan iterpretasi ikonologi. Tahapan ini merupakan tahapan esensial yang berangkat dari analisis terjoreksi pada tahapan analisis ikonografi. Menurut Panofsky sebagai intuisi sintesis yang sangat esensial (Panofsky, 1955 : 38).

Tinjauan ikonografi dan ikonologi berusaha untuk menghasilkan atraupun mengungkapkan makna interistik dari proses deskripsi pra ikonografi dan analisis ikonologi. Dalam mengungkap makna tahapan interpretasi ikonologi diperlukan teori bantu yang digunakan dalam kajian ialah teori symbol. Menurut berger, symbol adalah sesuatu yang memiliki kamampuan untuk mempengaruhi dan memiliki makna 
mendalam . pengertian symbol perlu dipelajari dengan semua jenis kejadian, pengalaman dan sebagain besar mempengaruhi emosional. Symbol membantu mempertajam tingkahlaku dan prestasi kebudayaan (Berger, 2010 : 28). Prinsip korektif pada tahapan interpretasi ikonologi ialah pada grjala kebudayaan yang sesuai dengan konteks dari objek. Kerangka komfirmasi ini diperlukan sebagai koreksi atas interpretasi sejarah kebudayaan dalam membangun symbolsimbol pada objek surya Majapahit. Ikon Surya Majapahit Sangat lekat pada keseharian masyarakat Mojokerto, terbukti dengan munculnya dinding-dinding pagar menggunakan menempelkan motifSurya Majapahit. Akan tetapi pada pengembangannya motif Surya tersebut tidak pernah dibuat perhiasan oleh pengrajin di desa Btan Krajan Kab. Mojokerto. Sehingga peneliti mencoba untuk mengembangkan produk perhiasan motif Surya Majapahit, sebagai usaha untuk memperkenalkan motif tersebut kedalam produk perhiasan.

\section{Estetika Ergonomi}

Dalam penelitian teori estetika digunakan untuk mendesain perhiasan sesuai dengan estetika dalam perhiasan. Estetika dalam penelitian mengacu pada eksplorasi bentuk motif-motif Majapahit, dengan mempertimbangkan nilai fungsional desain maupun produk perhiasan tersebut. Perhiasan termasuk dalam penerapan seni kriya logam, dan sebagai seni terapan. Peneliti menggunakan pendekatan estetika ergonomi dalam mengembangkan desain perhiasan perhiasan bermotif Majapahit. Estetika ergonomi tersebut dapat dilihat dari segi keamanan, kenyamanan produk dan kesehatan yang berorientasi pada keamanan, kesejahteraan dan kebahagiaan (Sachari, 1986: 80). Perhiasan tersebut memiliki nilai fungsi sehingga estetika ergonomi tersebut harus diterapkan, dikarenakan berhubungan langsung dengan manusia sebagai pengguna. Peneliti juga mempertimbangkan desain tersebut sesuai ergonomi karena penggunaan material nantinya menggunakan logam dan menghasilkan produk perhiasan. Estetika ergonomi dapat dikembangkan terhadap realita-realita dalam konseptual desain. Realiatas tersebut diantaranya fungsional, aman, terampil, ekonomis, estetis, dan sikap (Sachari, 1986:47). Dalam penelitian ini desain yang diciptakan menyesuikan dengan realitas yang ada. Desain yang dihasilkan adalah desain perhiasan dengan mengambil gaya klasik dan postmodern. Kedua gaya tersebut dipengaruhi oleh realitas tersebut. Realiatas tersebut seperti realitas fungsional, realitas tersebut berpengruh terhadap pengguna produk perhiasan tersebut. Pengguna berdasarkan umur maupun kelas sosial terhadap pemakai perhiasan tersebut. Realitas aman terhadap produk dihasilkan berdampak pada kenyamanan pengguna perhiasan, dengan melihat penggunaan logam perhiasan antara perak atau emas. Realitas terampil, seorang desainer dengan tanggung jawab untuk menghasilkan ranncangan perhiasan dengan menguai teknik. Sehingga dapat dikatakan desainer terampil memiliki sikap cekatan, tangkas, gesit, mampu, dan cerdik. Realitas ekonomis dalam penelitian ini desain perhiasan tersebut berpengaruh terhadap proses produksi perhiasan. nilai mahal ataupun murah dapat dilihat melalui desain tersebut kesederhanaan ataupun rumit. Konseptual desain menstranformasi ke realitas menurut Sachari antara lain:

\section{Realiatas fungsi}

Dalam peneliatian ini fungsi desain sangat berkaitan dengan segi pengguna produk perhiasan. dalam hal ini peneliti harus menelusuri aspek sosial yang berkembang di masyarakat. Mulai dari aspek jenjang sosial tertinggi, menengah, dan rendah.

\section{Realitas Aman}

Penelitian ini realitas aman dalam desain dapat diperhatikan dalam menentukan standart desain dan konsep desain sehingga membantu untuk merumuskan aktifitas dalam realitas aman.

\section{Realitas Terampil}

Dalam desain, terampil artinya menguasai bentuk informasi raba, informasi rasa, informasi data, dan informasi visual. Dalam penelitian pengembang buku desain ini peniliti harus menguasai material dan proses, penguasaan teknologi, berdasarkan penguasaan sistem dapat diartikan penguasaan secara teknik.

\section{Realiatas Ekonomis}

Dalam penelitian ini prasyarat desain, 
keberhasilan desain pada dasarnya juga diukur dari kelayakan ekonominya. Sehingga dalam desain perhiasan terbukti realitas ekonomis adalah penting. Terutama hal-hal yang menyangkut kriteria bentuk, proses produksi dan perawatan purna jualnya.

\section{Realiatas Estetis}

Dalam mendesain, intuisi lebih cenderung untuk mengemukakan ide-ide atau gagasan yang sifatnya langsung atau ekspresif. Dalam penelitian ini pencarian alternatif pemecahan masalah suatu desain atau pencarian bentuk desain yang tepat. Dapat diartikan pembedahan persepsi kearah proporsi seperti kesatuan, harmoni, irama, komposisi, keseimbangan. Sehingga intuisi dalam mewujudkan gagasan-gagasan estetis dalam karya-karya desain.

\section{Realitas Sikap}

Sikap merupakan modal awal dalam menerapkan gagasan atau ide kedalam sebuah karya. Antara sikap dan pertanggungjawaban adalah salah satu dimensi yang berjalan bersamaan didalam jiwa, Mengingat kebudayaan telah melangkah sangat jauh. Sehingga seorang desainer harus mempunyai sikap sehingga tidak mudah didekte oleh siapapun. Pada tahap akhir desain adalah realitas terakhir, dapat diartikan desain itu merupakan dunia sikap.

Adapun unsur ergonomis karya produk perhiasan motif Surya Majapahit tersebut adalah sebagai berikut:

a. Keamanan yaitu jaminan tentang keamanan untuk menggunaan produk perhiasan tersebut.

b. Kenyamanan yaitu apabila produk perhiasan tersebut digunakan, menonjolkan nilai praktis pada desain maupun hasil produk perhiasan.

c. Keluwesan pengguna hasil akhir pada penelitian ini adalah produk perhiasan motif Surya Majapahit termasuk pada produk terapan. Sehingga kemudahan dan keluwesan agar tidak terlalu kesulitan dalam penggunaannya.

\section{Design Thinking}

Menurut SP. Gustami terdapat beberapa tahapan penting dalam menciptakan karya antara lain eksplorasi, perancangan, dan perwujudan. Berdasarkan tiga tahapan tersebut dapat di uraikan menjadai enam langkah proses penciptaan karya. Enam langkah tersebut diantaranya: pengembaraan jiwa, menentukan konsep atau tema, merencang sketsa, penyempurnaan desain, mewujudkan karya, dan evaluasi (Gustami, 2007 : 230). Berdasarkan kutipan tersebut maka penelitian ini, dalam mengembangkan desain perhiasan melalui tersebut diantaranya pengumpulan data, pembuatan desain, pembuatan gambar kerja, proses produksi perhiasan, dan finishing. Dalam pembuatan desain dalam penelitian ini peneliti menggunakan unsur dan prinsip dalam mendesain.

Desain perhiasan dalam penelitian ini mengambil ide-ide maupun konsep-konsep bermotif Majapahit. Motif tersebut mengambil konsep dari artefak maupun simbol yang didapat setelah observasi dilapangan.

\section{Gaya Perhiasan \\ Perhiasan Klasik}

Benda-benda emas masa lampau tanpa membedakan fungsi masing-masing pada hakekatnya adalah seni para pande mas (Haryono, 1994: 6-7). Logam emas dalam kehidupan masyarakat Jawa Kuno digunakan untuk pembuatan artefak, dalam hubungan dengan barang-barang perhiasan, logam emas dipilih karena berpenampilan menarik dan memiliki warna yang indah (suvarna) selain itu, logam emas dianggap mempunyai nilai religius yang lebih jika dibandingkan dengan jenis logam lain (Haryono, 1991-1991: 6263). Logam emas adalah salah satu jenis logam disamping tembaga yang telah dimanfaatkan oleh manusia sejak ditemuan logam. Emas telah menarik perhatian manusia karena warna yang indah, oleh karena itu tidak mengherankan bahwa karena memiliki warna yang indah maka logam emas banyak dimanfaatkan untuk artefak ornamental (Haryono, 1991-1992: 1). Artefak sangat dekat dengan kebendaan yang berwujud atau dapat dianalisis, sehingga antara perwujudan sebuah artefak dan kehidupan manusia berjalan 
beriringan sesuai perjalanan waktu. Artefak juga merupakan tingkah laku manusia yang memfosil karena mengandung ide atau gagasan. Perhiasan emas dari masa klasik akhir di Jawa dibuat oleh ahli pembuat perhiasan yang dikenal sebagai pande mas, walaupun pande mas tergolong dalam golongan luar kasta (kasta rendah), bukan berarti pande mas disishkan dari lingkungan masyarakat. Perkembangan perhiasan pada masa klasik di Jawa juga tidak terlepas dari peran pande mas sebagai inovator, namun segala potensi yang dimiliki pande mas juga dipengaruhi berbagai hal yang ada diluar pande mas seperti waktu, ruang, kebudayaan, dan ketersediaan bahan (media), sehingga dengan tema yang sama memiliki bentuk yang berbeda.

\section{Perhiasan Postmodern (kontemporer)}

Moderenisasi kultural merupakan proses difrensiasi, maka postmodernisasi adalah proses dedifrensiasi.. jika teoritis peradigmatik modern adalah Weber, maka bagi yang postmodern bukan lagi Baudrillard, melainkan Walter Benjamin. Ada empat komponen utama yang dimiliki paradigma kultural yaitu (1) hubungan antara objek-objek kultural yang dihasilkan yaitu estetik, teoretis, etis, dan sebagainya; (2) hubungan antara yang bersifat kultural sebagai salah satu bagian yang utuh dengan yang bersifat sosial; (3) "ekonomi kultural" yang pada gilirannya memuat unsur-unsur kondisi bagi produksidan konsumsi, lembaga-lembaga kultur, model sirkulasi, dan produk kultural atau barang itu serndiri;serta (4) model penandaan: yaitu hubungan antara penanda, yang ditandakan, dan acuannya (Sugiharto 2004: 15). Menurut Lodra (2012:82) Gaya postmodernisme mengaplikasikan nilai-nilai pengetahuan tradisional dengan konsep penciptaan adaptif, adofsi, defusi, dan kolaborasi kraitif.

Koentjaraningrat mengungkapkan terkait dengan perkembangan yang dekutif sebagai berikut. "Proses penggeseran dan perkembangan pada masalah kebudayaan dikarenakan adannya internalisasi, sosialisasi, difusi, inovasi, dan ekulturasi, akibat keterbukaan budaya dengan budaya luar sehingga memicu terjadinya perkembangan. Perkembangan mulai dari bentuk kebudayaan yang sederhana kekreasi ke bentuk yang lebih komplek" (1990 : 227).

\section{Hasil Pengembangan Dan Visualisasi Desain Pengembangan Desain Perhiasan Surya Majapahit}

Untuk menjawab tentang konsep desain perhiasan motif Majapahit, peneliti menggunakan prosedur langkah penelitian pengembangan model Richey dan Klein (2007) planing, production, evaluation (PPE) dan teori Tim Brown (2009) Sesuai dengan teori tim Brown dalam tahapan design thinking yaitu eksplorasi, identifikasi, ideasi, visualisasi, evaluasi, dan persuasi. Berikut akan dibahas tahapan tersebut, maka di peroleh hasil dalam penelitian ini dapat diuraikan sebagai berikut:

\section{Planning (perencanaan)}

Dalam penelitian pengembangan desain perhiasan motif Surya Majapahit ini, peneliti melakukan survey di museum Trowulan Kab. Mojokerto. Dalam hal ini peneliti menemukan beberapa kerajinan logam berupa kelatbahu berbahan perunggu. Kemudian peneliti juga menemukan kowi sebagai alat untuk peleburan logam. Peneliti juga melakukan observasi di daerah Bejijong sebagai daerah atau sentra kerajinan cor kuningan. Peneliti juga belum menemukan pengrajin yang mengembangkan motifSurya Majapahit kedalam bentuk perhiasan. Adapun peneliti menemukan berupa Pin Surya Majapahit sebagai identitas satu komunitas kebudayaan di daerah Kab.Mojokerto. bersarkan Dari penggalian arkeologi di situs Trowulan kota pra islam terbesar di indonesia (Miksic 1990; 46) dan berdasarkan berbagai temuan emas tersebut menunjukkan bahwa teknik perwujudan perhiasan mencapai puncaknya karena berbagai tehnik pembuatan seni perhiasan emas telah di kenal baik (Kartodirjo Dkk 1993; 254).

Dengan kata lain kerajaan Majapahit memang di kenal sebagai kerajaan besar dan berbagai jenis tinggalan arkeologisnya yang telah di temukan menunjukan corak kebudayaan yang bermutu tinggi. namun ternyata tinggalan perhiasan dari masa Majapahit tidak sebanyak yang di harapkan. Berdasarkan penelitian diatas menunjukkan bahwa pada era Majapahit peradabannya sangat tinggi dengan temuan dari emas. Tetapi sangat disayangkan karena dalam menikmati perhiasan majapahit yang terbuat dari logam emas.

Tidak dapat dilihat di daerah Trowulan Kab. 
Mojokerto harus dating ke museum Nasional maupun Museum di Luar Negeri. Secara hipotesis Dr JLA Brandes pernah menyatakan bahwa jauh sebelum mendapatkan pengaruh dari kebudayaan India, bangsa indonesia memiliki pengetahuan dan kemampuan dalam bidang metalurgi. Pengetahuan metalurgi merupakan salah satu dari 10 unsur kebudayaan yang telah di miliki bangsa Indonesia yaitu wayang, gamelan. ilmu irama, puisi, membatik, mengerjakan logam, sistem mata uang, ilmu pelayaran, astronomi, penanaman padi, dan birokrasi pemerintahan. (Haryono 2008;60). Oleh sebab itu peneliti mengembangkan desain perhiasan Motif Surya Majapahit sebagai salah satu cara untuk mengembangkan warisan leluhur Majapahit, agar pengetahuan Metalurgi atau ilmu logam tidak punah.

Observasi selanjutnya peneliti juga menemukan di desa Batan Krajan Kab Mojokerto sebagai sentra perhiasan perak, sangat memprihatinkan untuk pengembangan produknya. Peneliti meninjau salah satu pengrajin, Bapak M Anam selaku pemilik usaha Fossil Silver. Mengemukakan bahwa saat peneliti melakukan wawancara, penerus usaha kerajinan perak pada saat ini kurang digemari oleh kalangan muda. Seluruh pegawainya banyak keluar untuk bekerja sebagai buruh pabrik. Dengan semakin mahalnya bahan baku, maka peminat juga kurang, demikian pula inovasi dalam desain perhiasan sangat kurang. Inovasi desain inilah yang menurut peneliti akan terus dikembangkan sebagai identitas daerah. Karena pengrajin hanya sebatas mengetahui kebesaran Majapahit sebagai sebuah cerita saja. Inovasi seperti Surya Majapahit ini sangat melekat pada daerah Kab.Mojokerto, tetapi banyak anak muda belum mengetahui makna dari Surya Majapahit. Peneliti banyak sekali menemukan logo maupun tempelan bangunan yang menggunakan Surya Majapahit, tapi sama sekali belum pernah membuat perhiasan menggunakan motif tersebut.

\section{Production (produksi) Eksplorasi}

1). Kerajaan Majapahit

Asal mula berdirinya kerajaan Majapahit yakni adanya serangan dari Jayakatwang (Adipati Kediri) yang berhasil membunuh
Kertanegara (penguasa kerajaan Singosari terakhir) akibat menolak membayar upeti. Kemudian Raden Wijaya berhasil melarikan diri ke Madura untuk meminta perlindungan kepada Arya Wiraraja. Raden Wijaya diberikan hutan Tarik oleh Arya Wiraraja sebagai daerah kekuasaannya dijadikan desa baru dan diberi nama Majapahit. Majapahit berasal dari kata buah Maja dan berasa pahit. Kemudian terdapat pasukan Mongolia tiba di pulau Jawa dengan tujuan menghukum Kertanegara akibat Kertanegara menolak membayar upeti kepada penguasa Jayakatwang. Situasi ini dimanfaatkan oleh Raden Wijaya untuk bekerjasama dengan tentara Mongolia menyerang Kerajaan Kediri. Kemudian pihak Mongolia menang atas terbunuhnya Jayakatwang. Ketika tentara Mongolia berpesta merayakan kemenangannya, Raden Wijaya memanfaatkan untuk menyerang tentara Mongolia. Akhirnya Raden Wijaya berhasil mengusir tentara Mongolia dari Jawa dan Raden Wijaya naik tahta dan bergelar Sri Kertajasa Jayawardana pada tahun 1293. Kerajaan Majapahit mencapai puncak kejayaan berada dibawah kekuasaan Hayam wuruk (1350-1389 M). berdasarkan kitab Negarakertagama. Wilayah kekuasaan Majapahit pada masa itu hampir sama luasnya dengan wilayah Indonesia yang sekarang, bahkan pengaruh Kerajaan Majapahit sampai negara tetangga.

\section{2). Surya Majapahit}

Pada tahapan ini peneliti melakukan observasi dan dokumentasi di Museum Trowulan pada tanggal 16 Juli 2019. Terletak pada pintu masuk halaman depan museum Trowulan terbingkai dengan kaca. Memperoleh data bahwa lambang Surya Majapahit sebagai simbol kebesaran kerajaan Majapahit. Dimana simbol tersebut dikaji objek visualnya terdapat 8 segitiga pada bagian tengah terdapat lingkaran. Dalam penelitian ini peneliti, juga menemukan motif-motif Surya yang digunakan sebagai aksesoris maupun arsitektur pada bangunan yang berada di Trowulan. 

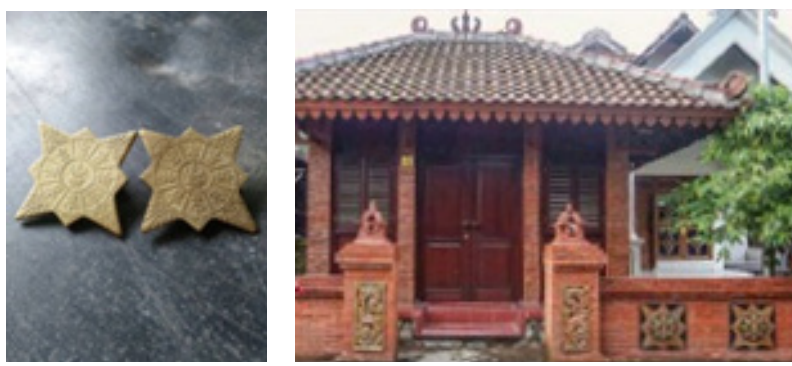

Gambar 1. Pin dan pagar Surya Majapahit desa Bejijong Trowulan Mojokerto (Sumber: Yongky Danang Prasetyo)

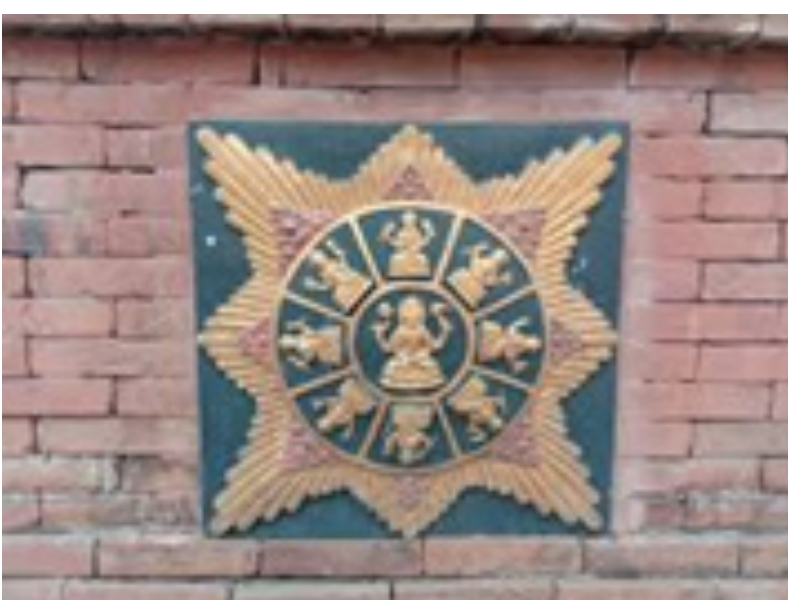

Gambar 2. Pagar Surya Mayapahit (Sumber: Yongky Danang Prasetyo)

Penelitian ini mengusung tema maupun konsep desain perhiasan bermotifkan Majapahit. Hasil pengembangan desain perhiasan tersebut tersebut diperuntukkan bagi pengrajin perhiasan di desa Batan Krajan Kab.Mojokerto, agar dapat menciptakan karakter dari masing-masing pengrajin. Dari beberapa desain perhiasan, menurut bapak Anam (48 tahun) selaku Pembina pengrajin perhiasan sekaligus pengrajin perhiasan. Bahwa motif surya Majapahit dianggap sangat kental dengan ciri khas dari Majapahit. Dengan hasil wawancara tersebut peneliti mengambil satu desain yang dianggap pengrajin sesuai dan dapat dikembangkan sebagai ciri khas bagi pengrajin perhiasan di Desa Batan Krajan yaitu motif surya Majapahit. Surya Majapahit pada objek visualnya ditengah lingkaran yang dikelilingi oleh juraijurai sinar matahari yang terbagi menjadi 8 ruang ber isi gambar dewa-dewa Hindu berpusat pada lingkaran kecil berisi pahatan siwa Lodra (2019: 3). Surya Majapahit berkembang pada kebudayaan Bali yaitu Lambang Dewata Nawasange dimana 9 dewa sebagai perlambangan kekuasaan dari Sembilan penjuru mata angina seperti Dewa
Brahma, Wisnu, Sambhu, Iswara, Maheswara, Rudra, Mahadewa, Sangkara, dan Siwa.

Dengan mengkaji ikonografi yang berkembang di Bali lambang Dewata Nawasange sebuah perwujudan dari bentuk akulturasi konsep sekte-sekte di Bali berkembang sebelum masuk pengaruh Majapahit dengan lambing surya Majapahit. Proses akulturasi diperkirakan terjadi pada masa kejayaan Majapahit, leh sempurna ketika kerajaan Majapahit jatuh dan diketahui tokoh-tokoh rohani Hindu, para Rsi menyingkir dan menetap di Bali (Lodra, 2019 : 169).

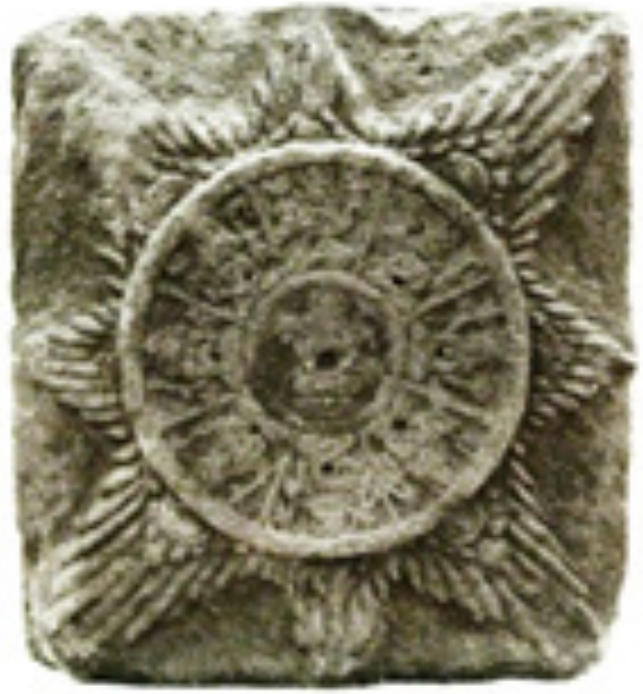

Gambar 3. Surya Majapahit

Koleksi Museum Trowulan, Kab.Mojokerto (Sumber: Yongky Danang Prasetyo)

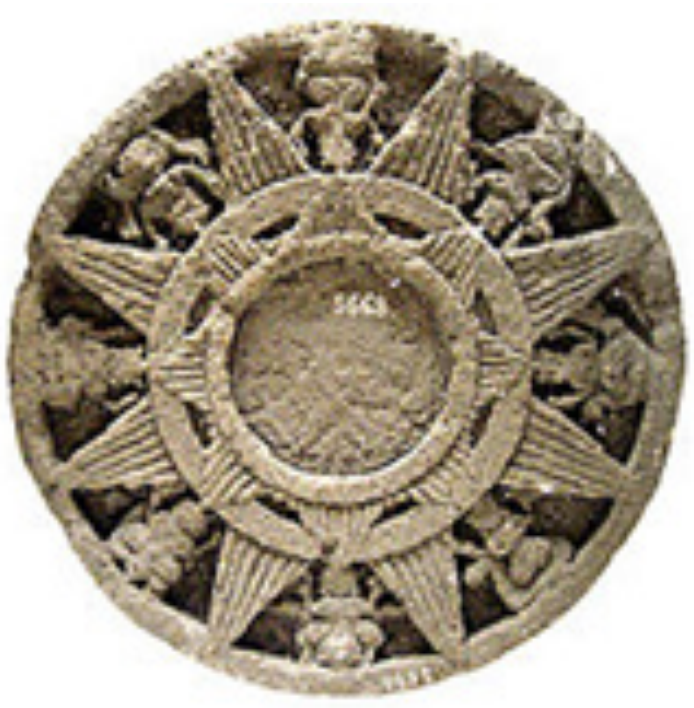

Gambar 4. Surya Majapahit Koleksi Museum Nasional, Jakarta (Sumber: Yongky Danang Prasetyo) 
Dengan uraian tentang Surya Majapahit tersebut, maka peneliti mengembangkan desain dengan memperhatikan ergonomi dalam produk perhiasan tersebut, sehingga kenyamanan dan nilai estetik diutamakan dalam menghasilkan desain maupun produk perhiasan. Peneliti dalam mengembangkan desain tersebut tanpa mengurangi nilai-nilai dalam lambang Surya Majapahit. Menurut I Nyoman Lodra (2019 : 168) bahwa Lambang Dewate Nawesange tidak hannya sekedar memiliki nilai estetik tetapi umat Hindu di Bali memiliki keyakinan pada masingmasing figure dewa, yang ada pada 9 penjuru mata angina memiliki filosofi warna, tugas, fungsi, dan makna seperti berikut:

a) Dewa Wisnu, utara, berfungsi sebagi pemelihara, dengan warna hitam yang di maknai ketakutan, kesucian, kesederhanaan, dan sebagainya.

b) Dewa Brama, selatan, berfungsi pencipta, warna merah bermakna sumber dari segala sumber, berani, cinta, api, darah, dan benih kehidupan.

c) Dewa Iswara, timur, warna putih dimaknai matahari, pelebur, dan sumber kebangkitan

d) Maha Dewa, Barat, kuning, dimaknai kemuliaan, keagungan fungsinya sebagai penjaga keseimbangan.

e) Dewa sengkara, Barat, warna hijau dimaknai tumbuhan, kehidupan, kesuburan berfungsi sebagai penyatuan.

f) Dewa Sambu, Timur Laut, warna Biru, sebagai pemelihara, permusuhan, kebebasan yang dimaknai hujan,banjir, dan kesedihan.

g) Dewa Mahesora. Tenggara Dadu fungsinya penjaga, keamanan, dimaknai kesadaran, kebangkitan, dan kedamaiaan.

h) Dewa Rudra, Barat daya, warna jingga fungsinya menjaga, pembasmi, kemurkaan, maknnya pengorbanan, penyerahan diri, bahaya, dan kehidupan.

i) Dewa Siwa, ditengah, bercampurnya seluruh warna putih, merah, kuning, hitam, fungsinya pelebur, pemusnah, maknanya kesucian.

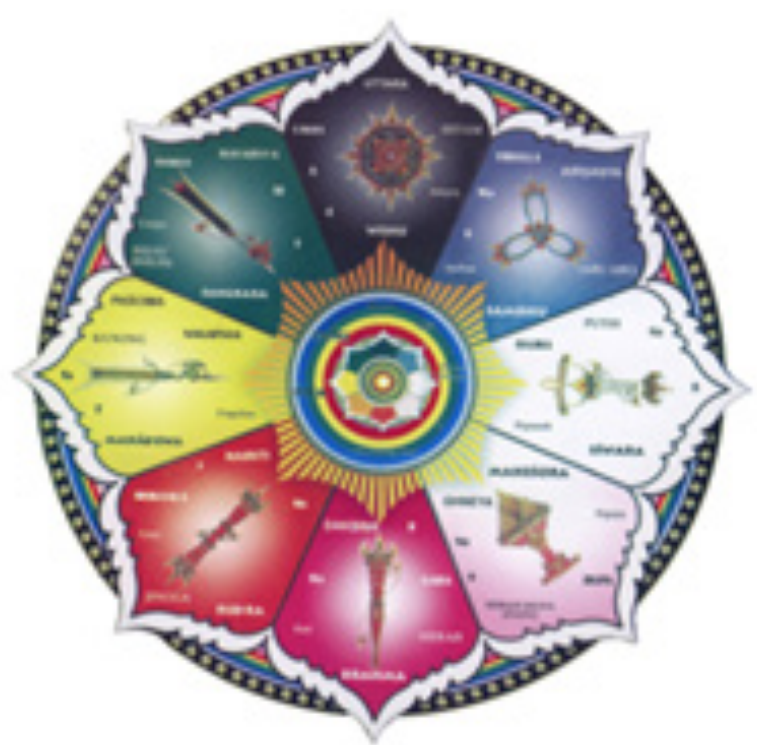

Gambar 5. Dewata Nawa Sanga

Sumber: https://cahayabaliblog.wordpress.com /2017/01/18/dewata-nawa-sanga/

\section{Identifikasi}

Dengan memperhatikan gambar tersebut peneliti menemukan bahwa surya majapahit sebagai ciri khas kab. Mojokerto, sehingga peneliti mengembangkan motif tersebut diaplikasikan dalam sebuah produk desain dan perhiasan. Peneliti mendapatkan gambaran bahwa motif Surya Majapahit terdiri dari bentuk diagonal yang tersusun bertingkat. Dapat dijelaskan dengan gambar sebagai berikut:

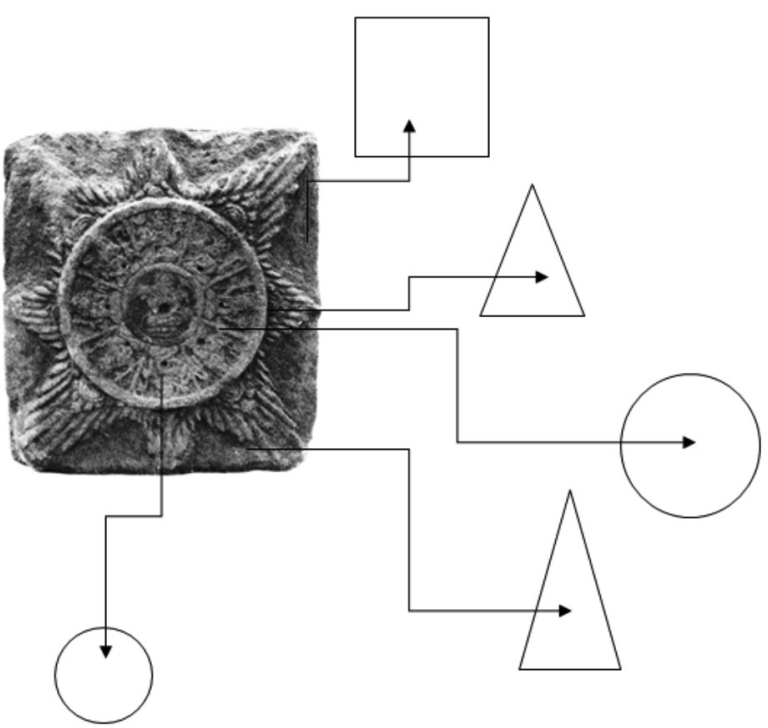

Gambar 6. Komponen Bentuk Surya Majapahit (Sumber: Yongky Danang Prasetyo) 


\section{Idea}

Tahapan ini untuk menemukan gagasan maupun ide kreatif dalam mengembangkan desain perhiasan motif surya Majapahit. Peneliti menggunakan dua gaya dalam mendesain perhiasan tersebut yaitu gaya klasik dan gaya postmodern. Setelah melakukan eksplorasi dan identifikasi maka peneliti merujuk kepada salah satu lambang Majapahit. Lambang tersebut adalah Surya Majapahit, yang memiliki komponen dan makna yang mengutkan dalam mengkonsep desain perhiasan. Peneliti mengambil Surya perhisan dan mengkombinasikan dengan ragam hias Majapahit. Yang diambil dari beberapa rujukan diantaranya.

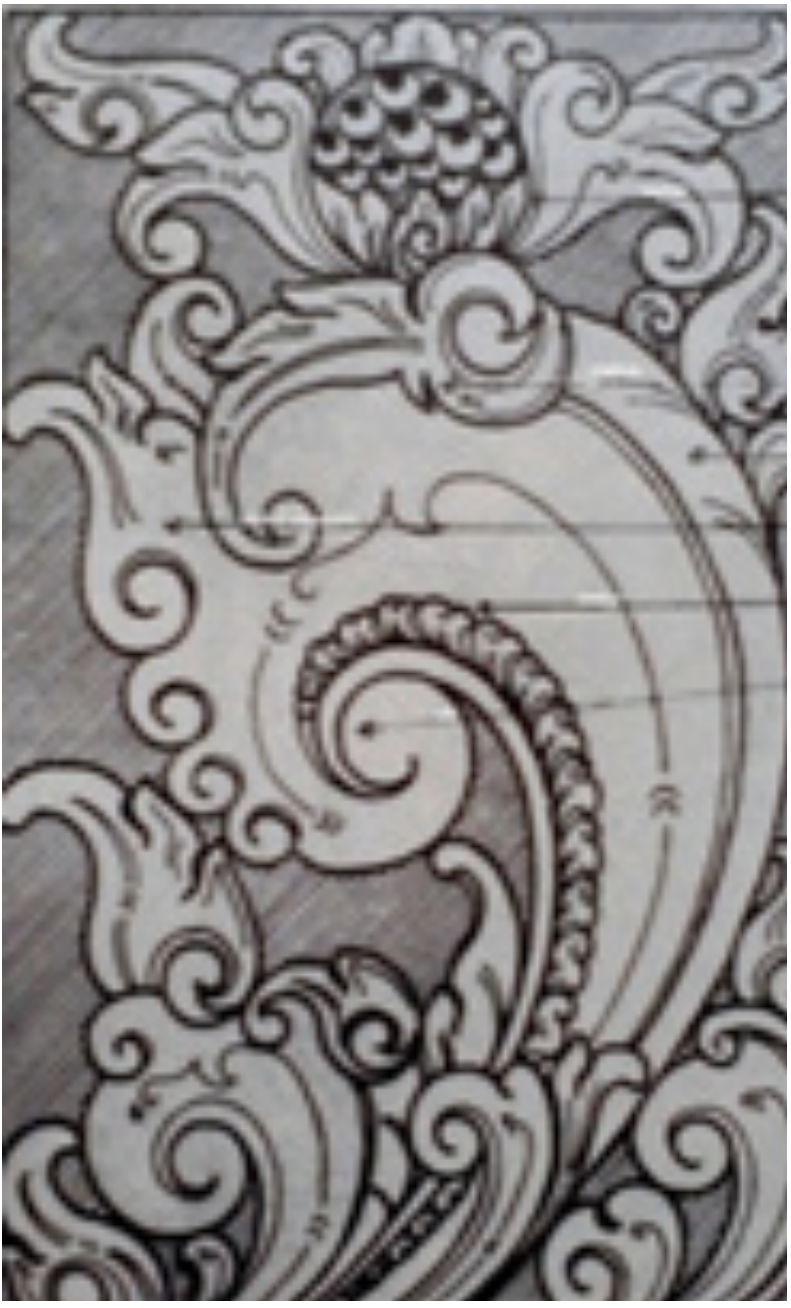

Gambar 7. Seni Ukir Motif Majapahit Sumber: seni ukir Bastomi (1986 : 25)

Gambar di atas merupakan motif ukir Majapahit memiliki ciri-ciri sebagai berikut:

1) Angkup, berbentuk cekung dan berikal. Berada pada bagian atas dan pada ujung angkup terdapat ikal sebagai akhir angkup tersebut.

2) Jambul susun, terletak pasa muka daun pokok dengan pengulangan bentuk berkali-kali.

3) Daun Trubus, terletak pada pangkal depan dari daun pokok.

4) Benangan, terdapat pada daun pokok bagian depan mulai dari pangkal mengikuti alur lengkung daun pokoknya menuju dan berakhir pada ulir atau ukel.

5) Pecahan, ada dua jenis pecahan yaitu pecahan garis yang menjalar pada daun pokok dan pecahan cawen yang terdapat pada ukiran daun patran.

\section{Visualisasi}

Dengan memperhatikan tahapan eksplorasi, identifikasi, dan idea, maka peneliti memvisualisaikan kepada desain perhiasan. Pada tahapan ini peneliti memvisualisasikan kedalam bentuk 2 dimensi dan 3 dimensi, dengan menggunakan manual dan program corel draw x4 dalam mendesain perhiasan. Pada obyek visual ini menunjukkan dari idea yang sudah diuraikan sebelummnya mengambil motif Surya Majapahit dengan mengkombinasikan beberapa objek pendukung. Objek desain tersebut tidak menggurangi makana didalamnya hannya mengembangkan pada sisi pengembangan bentuk. Desain tersebut dapat digambarkan sebagai berikut:
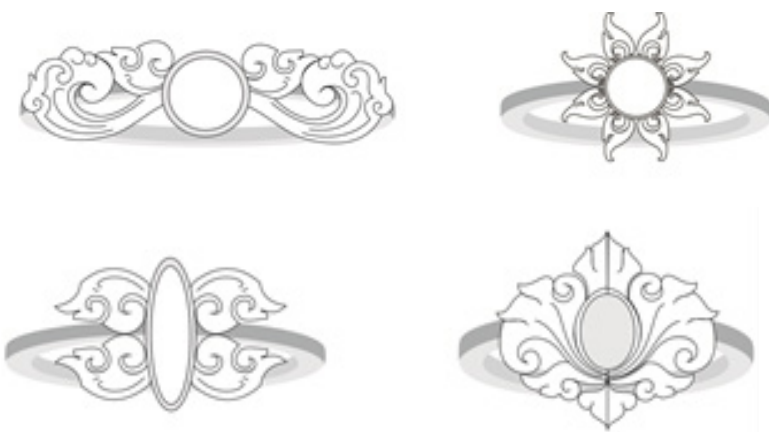

Gambar 8. Pengembangan desain cincin klasik (Sumber: Yongky Danang Prasetyo) 

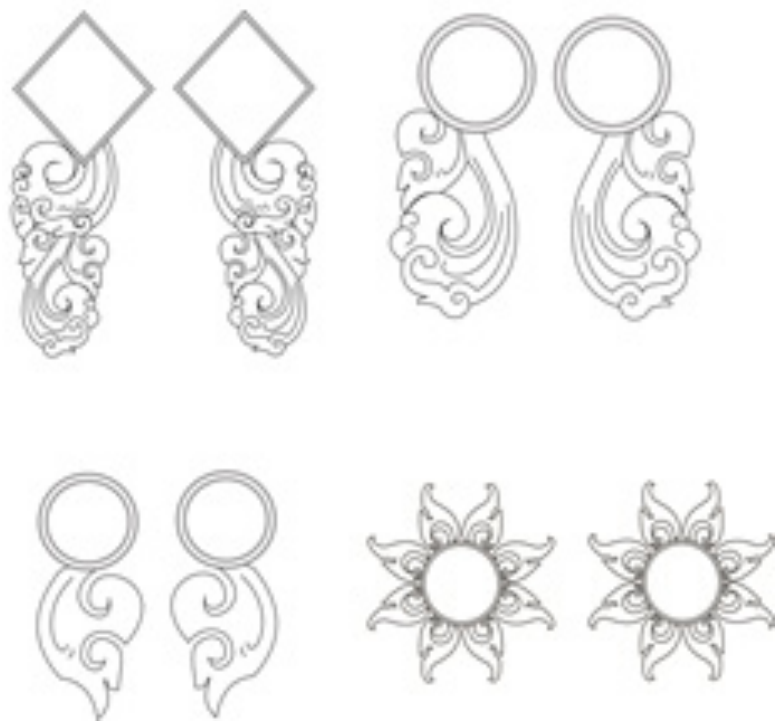

Gambar 9. Pengembangan desain anting-anting klasik (Sumber: Yongky Danang Prasetyo)
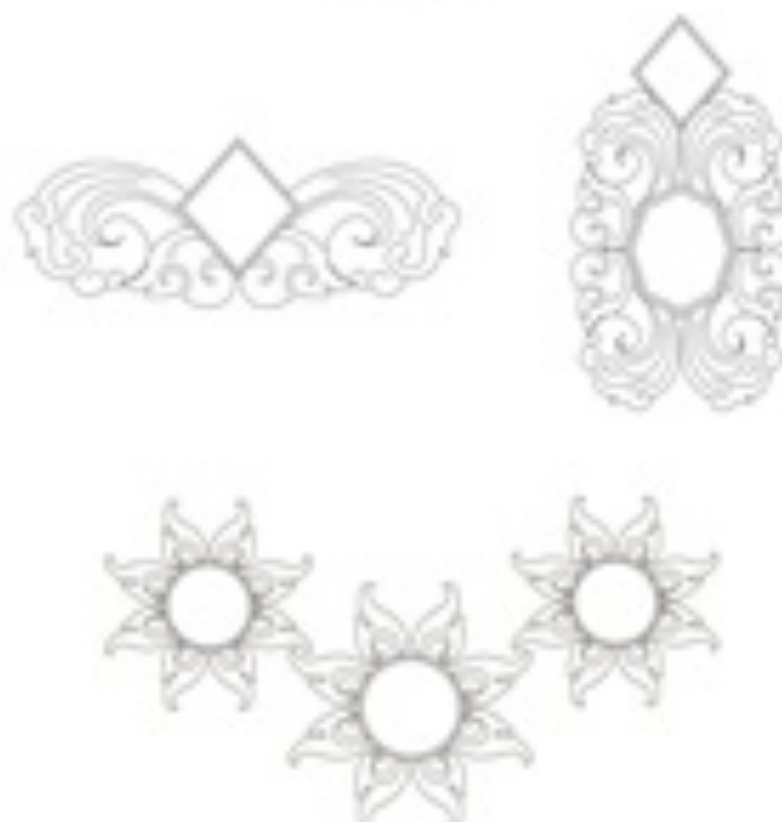

Gambar 10. Pengembangan desain liontin klasik (Sumber: Yongky Danang Prasetyo)
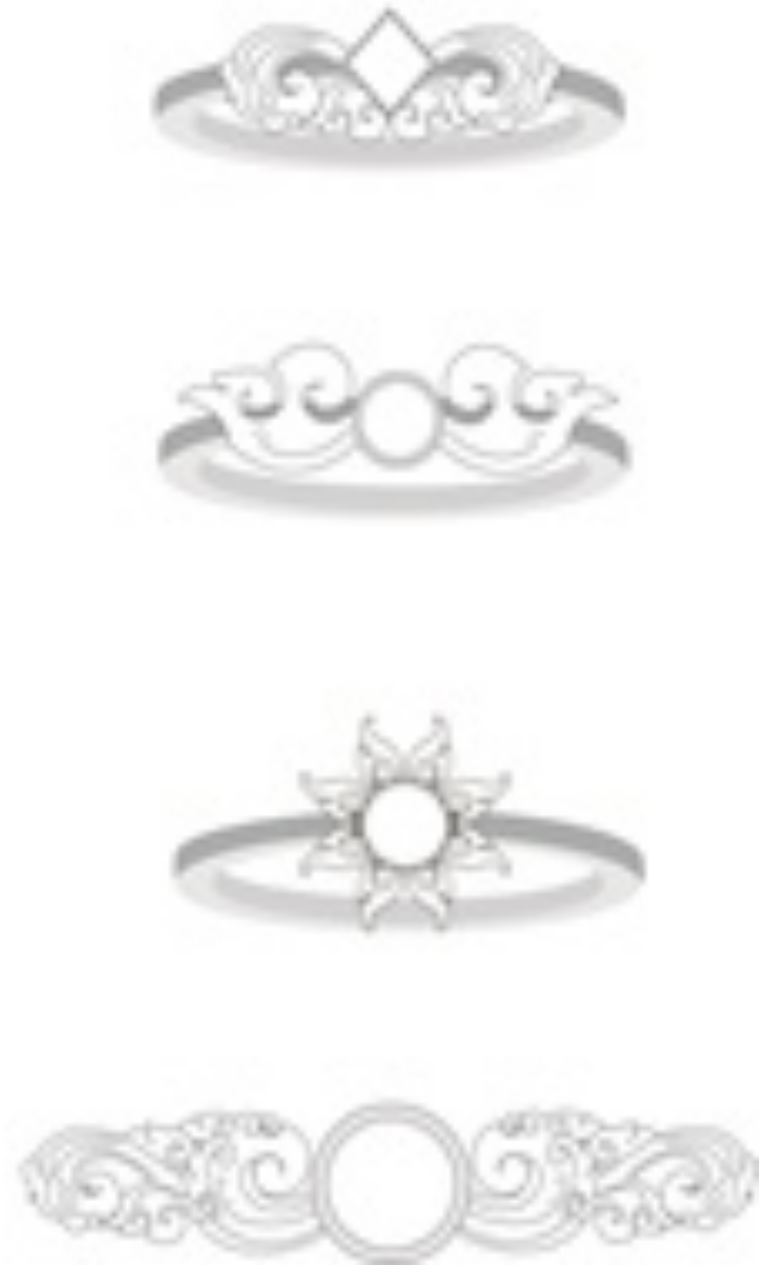

Gambar 11. Pengembangan desain gelang klasik (Sumber: Yongky Danang Prasetyo)
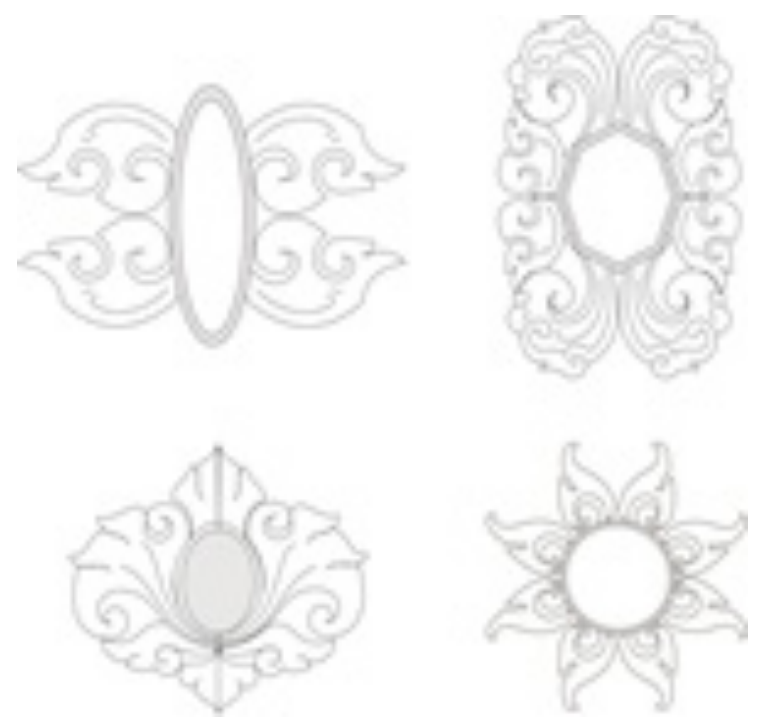

Gambar 12. Pengembangan desain bros klasik (Sumber: Yongky Danang Prasetyo) 

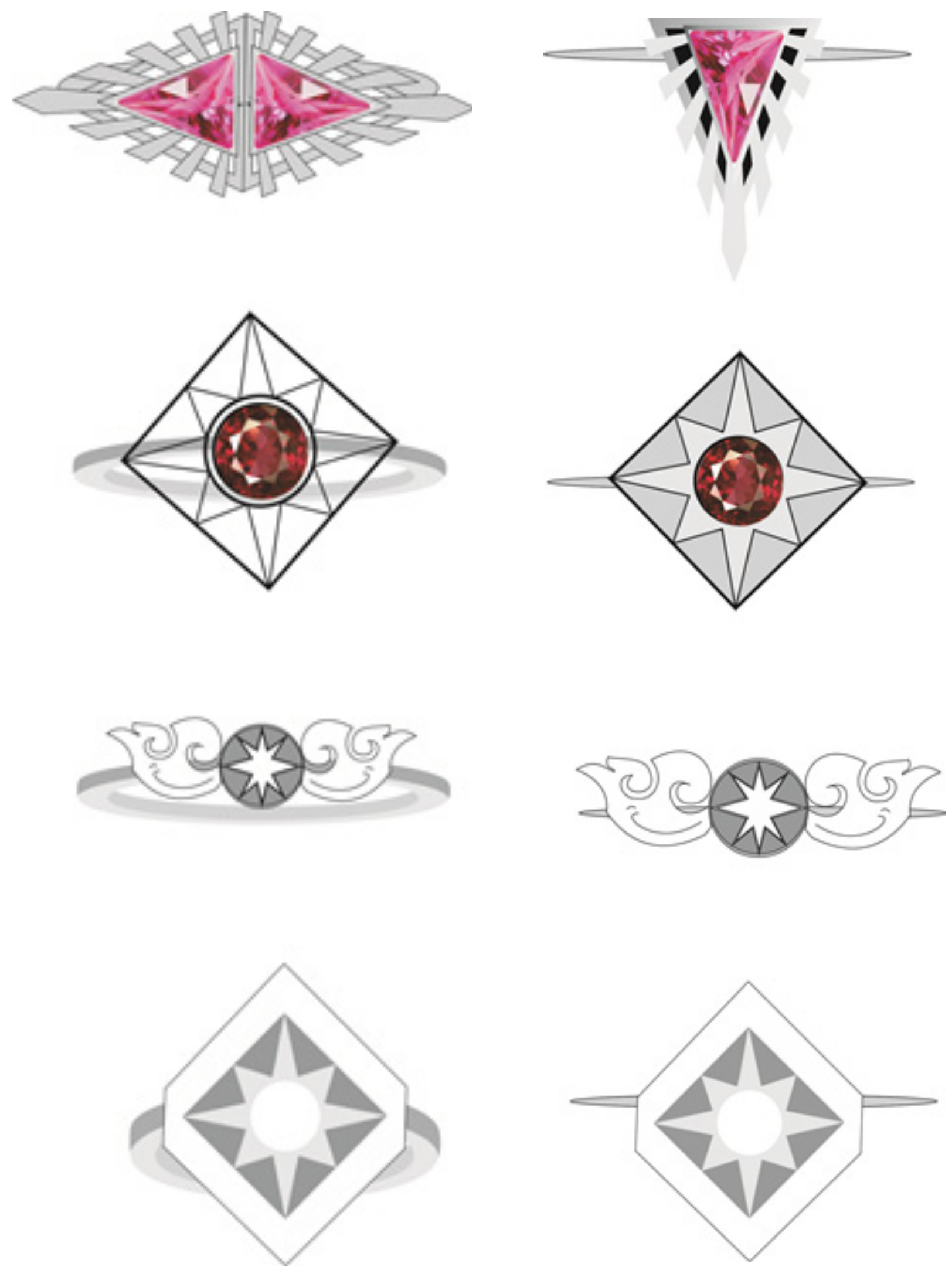

Gambar 13. Pengembangan desain cincin postmodern (Sumber: Yongky Danang Prasetyo)

Gambar 14. Pengembangan desain bros postmodern (Sumber: Yongky Danang Prasetyo) 

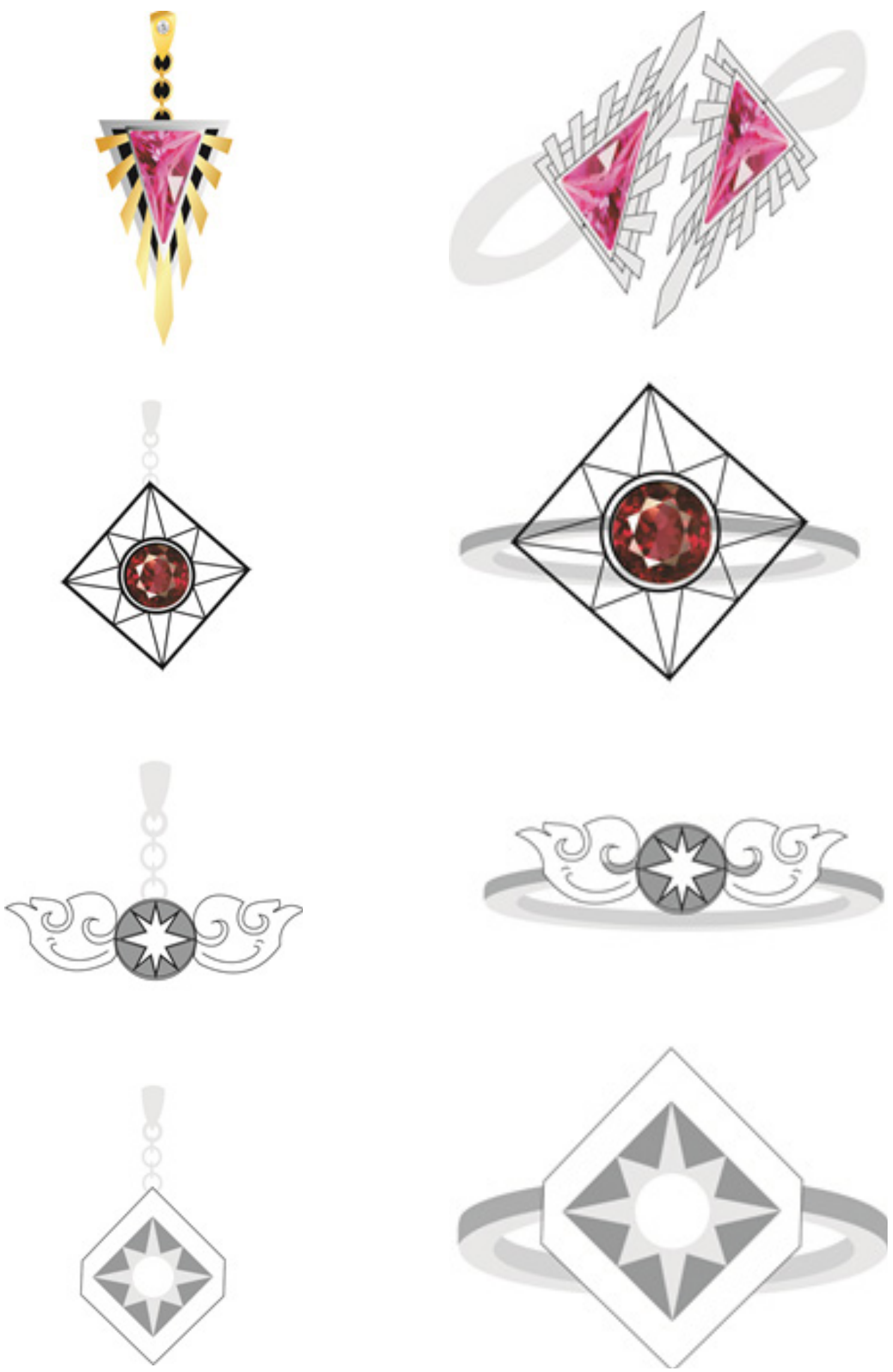

Gambar 15. Pengembangan desain liontin postmodern (Sumber: Yongky Danang Prasetyo)
Gambar 16. Pengembangan desain gelang postmodern (Sumber: Yongky Danang Prasetyo) 

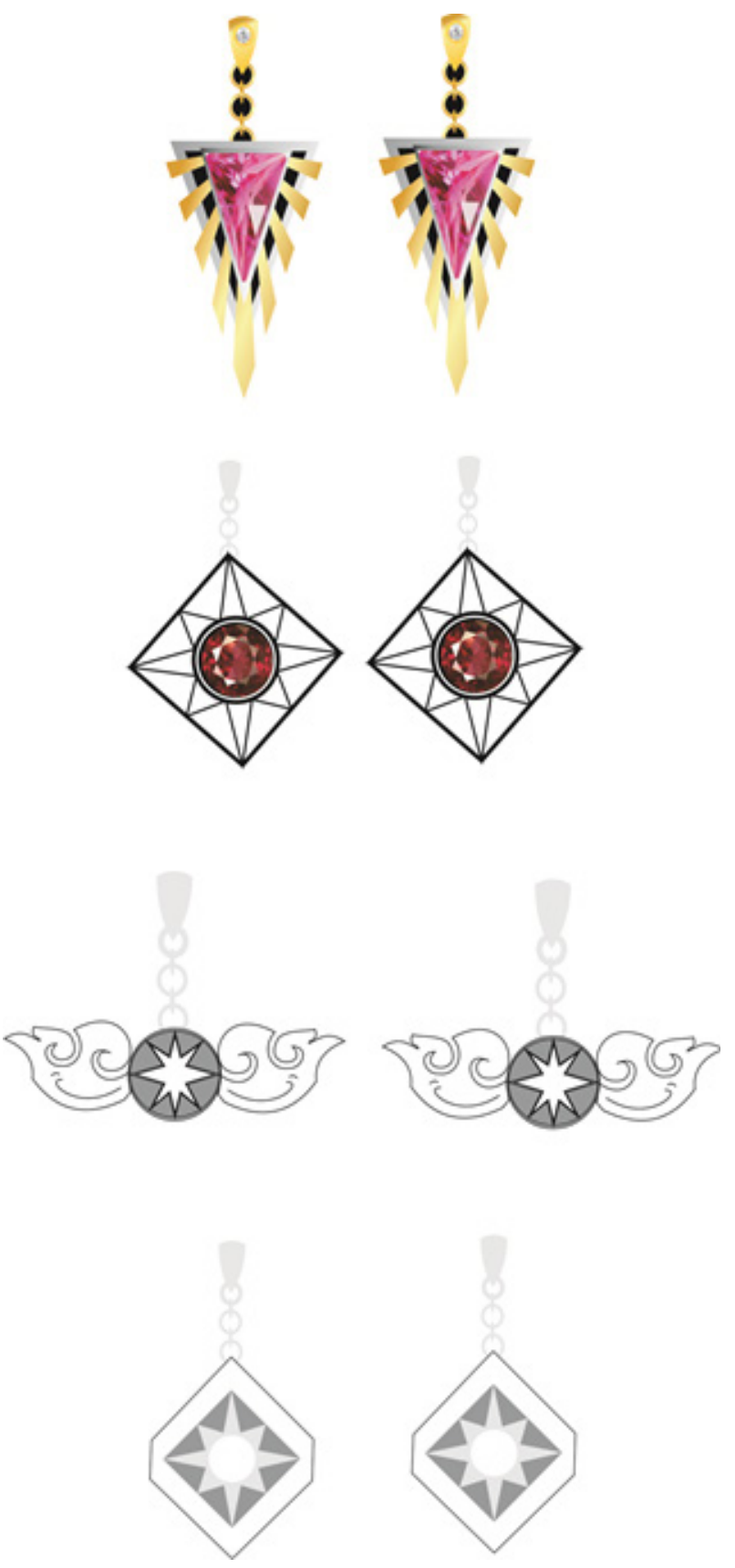

Gambar 17. Pengembangan desain anting postmodern (Sumber: Yongky Danang Prasetyo)

\section{Evaluasi}

Dengan memperhatikan desain yang sudah dikembangkan sebelum memasuki pada tahapan persuasi. Peneliti mengevaluasi atas desain dengan bantuan expert yang ditunjuk sebelumnya, sehingga mendapatkan temuan dalam desain tersebut yaitu ada beberapa desain yang memerlukan perubahan berkenaan dengan teknik produksi. Beberapa desain tersebut mengurangi dan menambah bagian agar nyaman saat digunakan oleh konsumen. Penelitian ini mengambil dua desain dengan gaya klasik dan postmodern (kontemporer) yang sudah dikembangkan untuk dijadikan perhiasan. Desain perhiasan ini telah diuji oleh ahli desain bu lidya (38 tahun) dan perhiasan bapak Anam (54 tahun) diperoleh hasil bahwa menurut bu lidya mengemukakan untuk keseluruhan desain cukup bagus sesuai dengan tema atau motif yang dikembangkan. Pemilihan tema tersubut sangat perlu dikembangkan karena beberapa waktu lalu bu lidya jarang mengetahui pengrajin Kab.Mojokerto berpameran dalam pameran nasional maupun internasional.

$\mathrm{Bu}$ Lidya mengemukaan bahwa salah satu desain cukup mewakili, yaitu motif Surya Majapahit dengan berbentuk bunga masing-masing kelopaknya menggunakan ornamen Majapahit. Menurut beliau desain tersebut sangat menarik karena memadukan banyak unsur didalamnya yaitu bunga dan Surya Majapahit. Hasil produk tersebut sudah mengembangkan dengan teknik dengan berbahan rhodium sebagai produk sekarang yang banyak digemari oleh konsumen. Sedangkankan untuk pengembangan postmodern bu Lidya memilih desain sinar surya majapahit yang menjurai keluar. Tetapi dalam desain tersebut perlu diperhatikan dalam segi keamanan, karena jang sampai pada sudut tersebut melukai konsumen pada saat menggunkan produk tersebut.

Wawancara dengan ahli perhiasan bapak Anam, sangat tertarik dengan pengembangan desain Surya Majapahit sebagai ciri khas dari Kab.Mojokerto. menurut bapak Anam dengan mengembangkan desain tersebut dapat membangkitkan gairah dalam pengrajin untuk kembali menekuni kerajinan perak ini. Pada saat ini pengrajin yang bertahan hanya 10 orang saja, dengan berkurangnya pengrajin ini hanya 2 unit usaha yang bertahan hingga sekarang. Melihat keadaan tersebut bapak Anam sangat antusis kepada peneliti untuk terus mengembangkan desain perhiasan dengan motif Majapahitan yang lain. Karena kekurangan media maupun pengrajin yang mampu dalam mendesain perhiasan motif Majapahit saaat ini. Dalam tahapan evaluasi ini bapak Anam tertarik dengan desain Surya Majapahit berbentuk seperti bunga. Desain tersebut cukup bagus tetapi untuk arah ornamen tersebut lebih baik searah dengan jarum jam sehingga keseimbangan dalam bentuk tersebut tampak. 

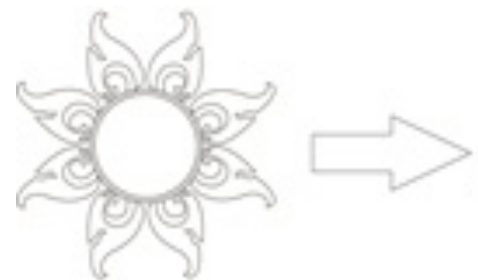

SEBELUM

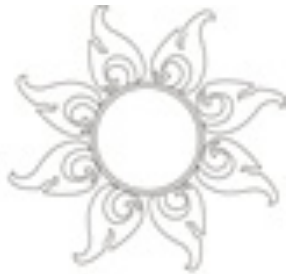

SESUDAH
Gambar 18. Evaluasi desain (Sumber: Yongky Danang Prasetyo)

\section{Persuasi}

Tahapan akhir penelitian mewudkan dengan material perak dengan finishing poles dan rhodium plating. Penelitian ini mewujudkan perhiasan dengan mengambil gaya klasik dan gaya postmodern. Perwujudan sesuai ergonomic dengan memfokuskan kepada kenyamanan pengguna., sehingga perhiasan tersebut dapat menunjang dari segi fasion dan segi keamanan perhiasan. Perhiasan klasik penelitian pengembangn desain ini dengan obyek atau sumber ide Surya Majapahit, dengan menggabungkan motif ukir majapahit yang diambil dari museum Trowulan. Desain tersebut tidak mengurangi dari nilai filosofi lambang surya majapahit dengan mengkaji ekonografinya, dasain tersebut hanya mengembangkan pengembangan komponen bentuk dari hasil identifikasi.

Desain post modern pada penelitian ini dengan mengambil bentuk sinar dari Surya Majapahit. Desain tersebut menggunakan material perak dengan hasikl tahap akhirnya dengan teknik poles dan rhodium plating . untuk membedakan antara desain klasik dan postmodern terdapat pada penambahan material dan fungsinya diantaranya untuk kalung digunakan juga material dari bahan kain. Kemudian, pada bros dapat digunakan untuk aksesoris jilbab.

\section{Evaluation (Evaluasi)}

Pada tahapan evaluasi ini keselurahan pengembangan desain perhiasan motif Surya Majapahit untuk pengrajin di Desa Batan Krajan Kab.Mojokerto, menemukan beberapa permasalahan diantaranya:

a. Pada tahapan eksplorasi peneliti belum menemukan produk perhiasan motif Surya Majapahit, sehingga peneliti memfokuskan dan merumuskan masalah bahwa pengrajin perhiasan di Batan Krajan Kab. Mojokerto, belum pernah membuat desain maupun memproduksi perhiasan dengan motif tersebut. Peneliti mengembangkan desain Surya Majapahit tersebut kedalam bentuk produk perhiasan perak dengan model klasik dan post modern.

b. Pada tahapan perancangan ideasi untuk produksi perhiasan beberapa ide kreatif desain kesulitan dalam proses produksi. Terutama pada proses ukir tekan pada ornament motif Majapahit. Kesulitan tersebut dikarenakan jarang dibuat dan Sumber Daya Manusia dalam hal ini pengrajin sudah tidak ada lagi yang mampu untuk membuat detail.

c. Secara teknologi pengrajin menggunakan alat tradisional untuk produksi perhiasan perak tersebut.

d. Pengrajin perak di desa Batan Krajan Kab. Mojokerto memerlukan komposisi bahan untuk mengembangkan produk pada tahapan finishing. Pengrajin hanya sebatas mengetahui pelapisan perhiasan dengan Rhodium, dan masih belum menggunakan tahapan tersebut.

e. Pada tahapan evaluasi desain perhiasan peneliti merubah atau merevisi beberapa inci bagian komponen perhiasan untuk menyempurnakan desain tersebut. Revisi tersebut terdapat pada desain Surya Majapahit dengan model Klasik yang memerlukan tingkat kedetailan dan pematrian yang rumit. Merevisi desain tersebut didapat dari penilaian dari para ahli desain dan produk perhiasan.

f. Pada penelitian pengembangan desain perhiasan ini pada proses produksi peneti mengalami hambatan pada pengadaan bahan perak murni mengalami keterlambatan, sehingga pada proses produksi lebih lama dan tidak sesuai dengan jadwal penyelesaian.

g. Pada proses produksi produk perhiasaan Surya Majapahit peneliti memperinci kebutuhan bahan, alat, dan harga sebagai berikut : 
Table 1 Daftar Kebutuhan Produksi

\begin{tabular}{|l|l|l|l|}
\hline No & Nama barang & Satuan & Harga \\
\hline 1 & Perak dan patri & $@ 300$ gram & Rp. 6.000.000,- \\
2 & Bensin & & Rp. 30.000,- \\
3 & Mata gergaji & & Rp. 245.000,- \\
& shawing Jerman & & Rp. 1.000.000,- \\
& Biaya produksi & @ 2set & Rp. 1.300.000,- \\
4 & Biaya Rhodium & perhiasan & Rp. 600.000,- \\
5 & Batu mulia & @ 2set & \\
\hline & & perhiasan & \\
\hline & Total produksi & & Rp. 9.175.000,- \\
\hline
\end{tabular}

h. Pada biaya produksi Rp. 9.175.000,- untuk 2 set perhiasan menurut masukan dari beberapa ahli bila harga jual produk desain motif Majapahit tersebut ditambah keuntungan 15\% sehingga menjadi Rp. 10. 551.250,masih sesuai dengan daya beli konumen pada kelas menengah dan atas.

\section{Kualitas pengembangan perhiasan motif Surya Majapahit}

Dalam tahapan mendeskripsikan kualitas produk perhiasan dengan tahapan memperinci masing-masing komponen kedalam bentuk table kerja. Table kerja ini mempermudah untuk mengerjakan perhiasan, sehingga dapat terukur dari bagian perhiasan yang akan diwujudkan. Sekaligus mendeskripsikan rancangan sumber ide berupa desain dan produk perhiasan sesuai dengan pengembangan perhiasan bergaya klasik dan postmodern

1. Desain pehiasan Klasik

Desain perhiasan bergaya Klasik menggunakan simbol Surya Majapahit dengan ikonografi 8 sinar dengan bentuk utama bentuk lingkaran. Desain perhiasan klasik tersebut untuk menunjukkan nilai-nilai tradisional, maka peneliti menggabungkan ornamen relief Majapahit kedalam bentuk perhiasan. Desain klasik yang dibuat dikhususkan pada kalangan kelas menengah hingga atas. Kesan perhiasan tersebut terlihat elegan dengan menambahkan komponen batu mulia. Desain perhiasan motif Surya Mjapahit tersebut diaplikasikan kedalam bentuk perhiasan berbahan perak atau silver. Desain tersebut sudah melalui tahapan validasi oleh tim validator dari pengrajin. Adapun tanggapan mengenai desain sebelum produksi perhiasan bergaya klasik, terdapat pembenahan diantaranya sudut arah sinar menyesuaikan arah jarum jam.

Untuk menambah kesan kokoh pada tahapan desain menambah rangkaian kawat pada bagian bawah. Penambahan tersebut untuk memberikan kesan nyaman dan aman, sehingga berdampak pada nilai-nilai realitas fungsional, aman, terampil, dan estik. Pemanfaat media aplikasi corel draw membantu peneliti untuk menggambarkan rancangan perhiasan berupa gambar 2 dimensi maupun 3 dimensi. Unsur-unsur desain dan prinsip desain diutamakan dengan memperhatikan, bahwa produk perhiasan adalah produk terapan berbahan logam dengan teknik pengerjaan yang berbeda dengan desain produk lain. Ketepatan ukuran dan kekuatan dalam proses desain sangat diperhatikan untuk mencari ketepatan pada produk perhiasan. Keseluhan perhiasan dikerjakan menggunkan alat manual tanpa menggunakan mesin ataupun teknik cor untuk produksi masal. Produksi perhiasan menghasilkan 1 set perhiasan diantaranya gelang, liontin, cincin, bros, dan anting-anting. Sebagai berikut benruk rancangan desain perhiasan motif surya Majapahit dengan gaya klasik.
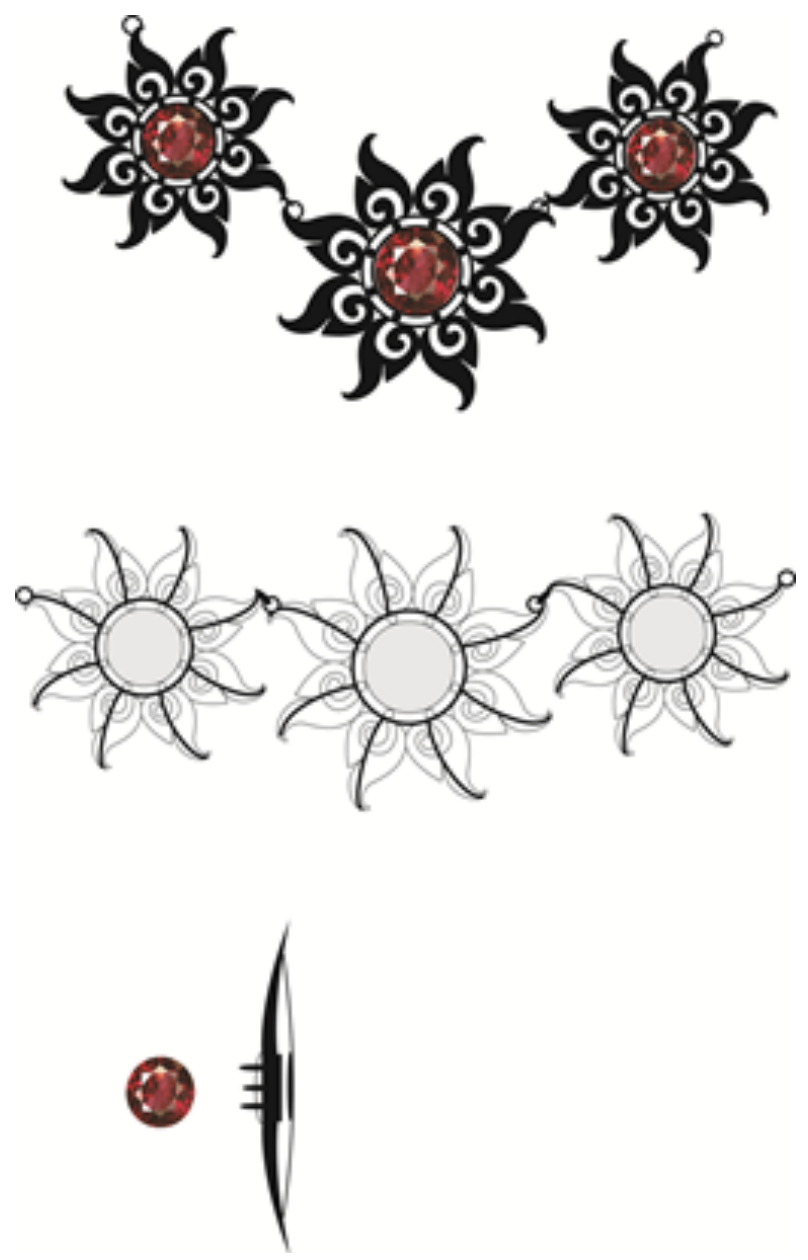

Gambar 19. Desain Liontin Surya Majapahit (Sumber: Yongky Danang Prasetyo) 

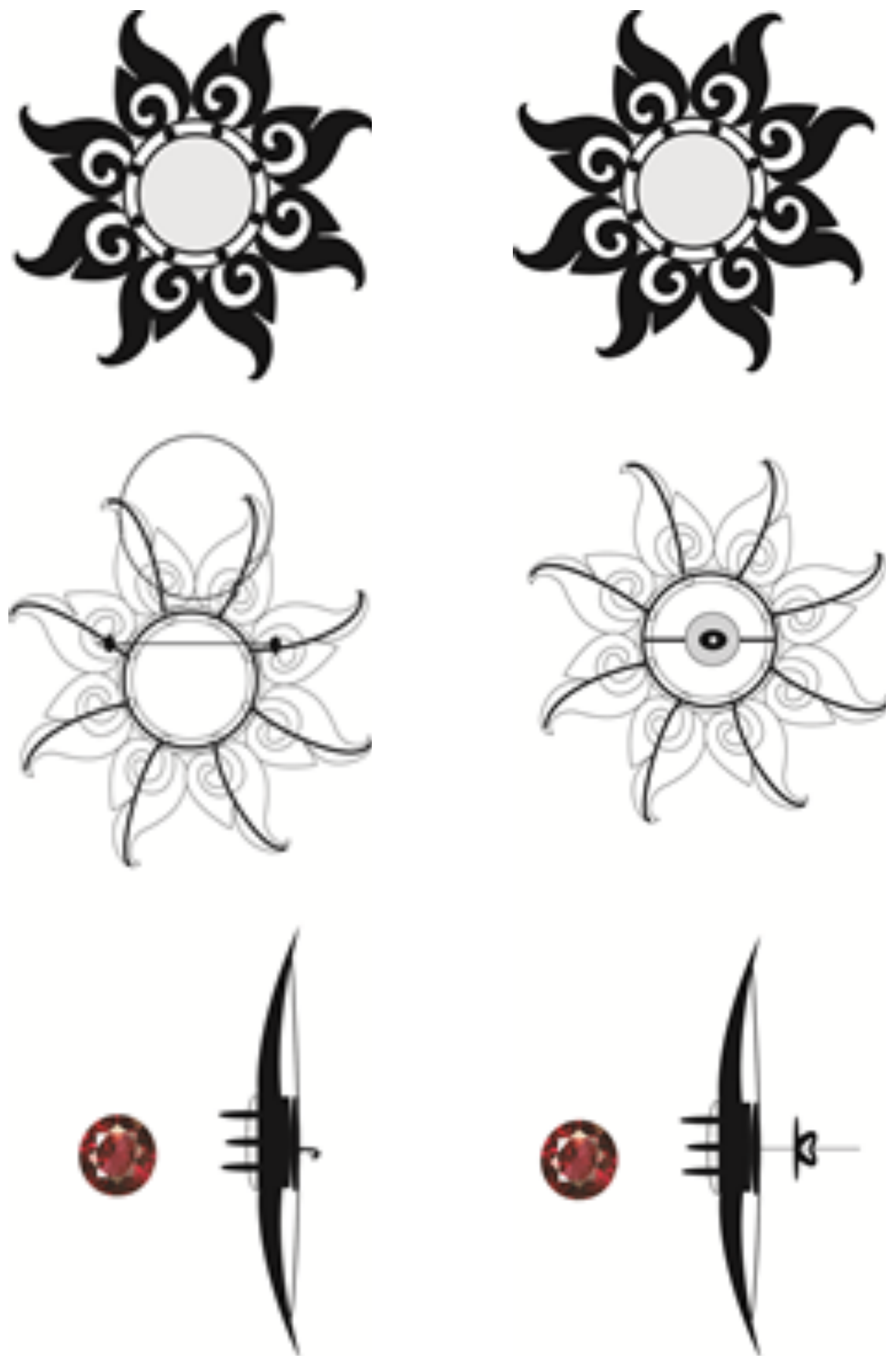

Gambar 20. Desain Bros Surya Majapahit (Sumber: Yongky Danang Prasetyo)

Gambar 21. Desain Anting Surya Majapahit (Sumber: Yongky Danang Prasetyo) 

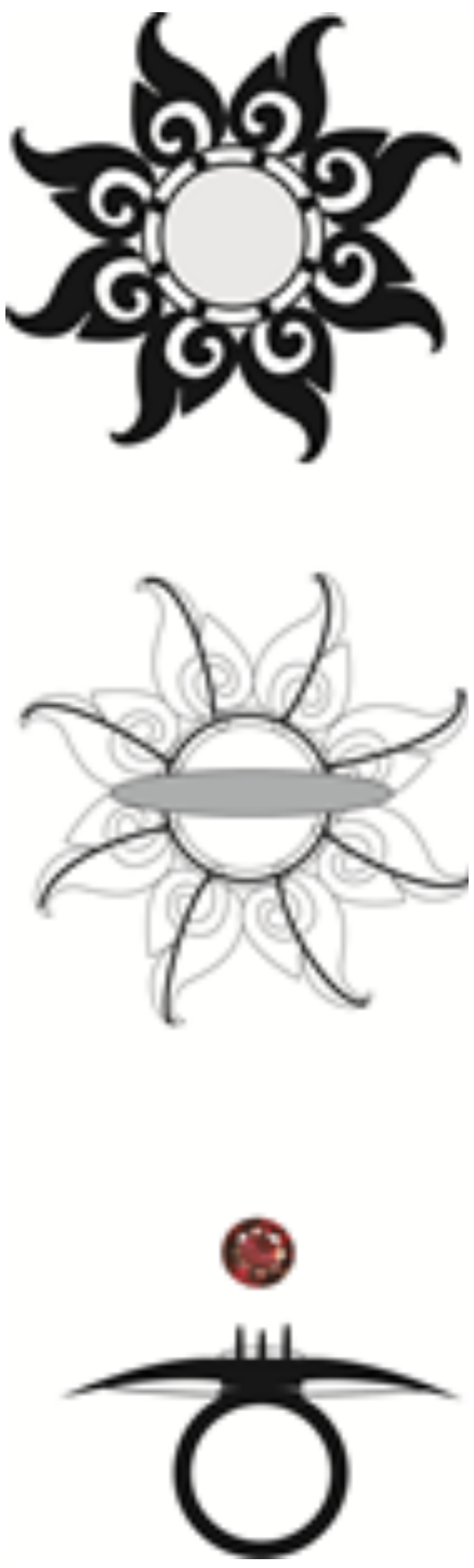

Gambar 22. Desain Cincin Surya Majapahit (Sumber: Yongky Danang Prasetyo)
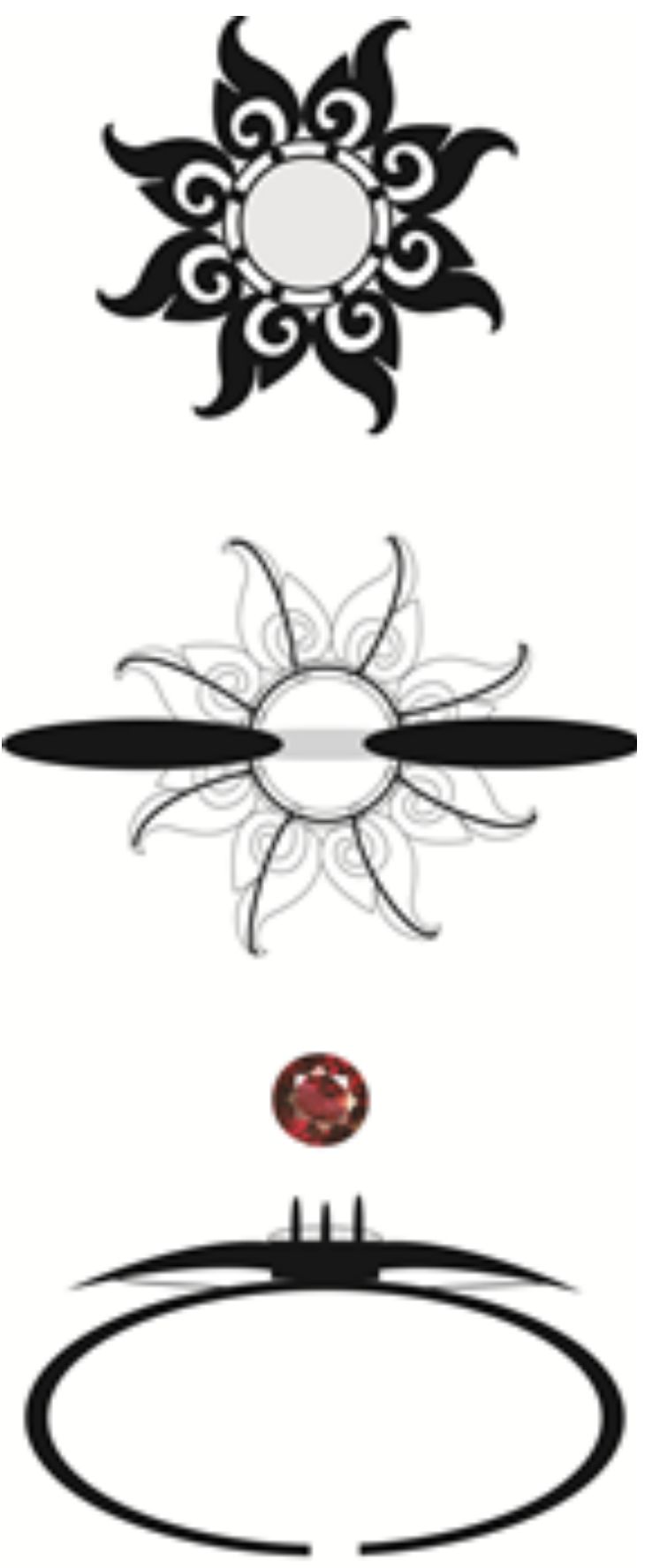

Gambar 23. Desain Gelang Surya Majapahit (Sumber: Yongky Danang Prasetyo)

\section{Desain postmodern kontemporer}

Desain perhiasan post modern ini peneliti merancang lebih sederhana dibandingkan, rancangan klasik. Keserhanaan dalam desain sebagai gambaran peneliti untuk menunjukkan nilai fungsional dan ekonomis. Pengguna produk perhiasan, nantinya dapat digunakan pada kelas bawah maupun menengah. Peneliti tetap menggunakan motif Surya Majapahit. Perancangan desain gaya postmodern ini menggambil salah stu bentuk diagonal segi tiga 
sama kaki dengan motif sinar yang menjorok keluar. Sesuai dengan teori ikonografi peneliti tidak meninggalkan tema ataupun konsep perancangan Surya Majapahit. Perancangan desain ini masih membawa desain klasik, digunakan dengan percampuran bahan baku perak dilapis rhodium. Teknik pekerjaan masih menggunakan manual, dengan alat sederhana dan menunjukkan ornamen diagonal untuk menunjukkan kekuatan pada produk tersebut. Peneliti masih menunjukkan pada desain perhiasan postmodern dengan memperhatikan nilai ergonomi, walaupun terlihat sesderhana masih memperkuat dengan mementingkan kenyamanan pengguna. Unsur desain dan prinsip desain dengan mengkomposisikan bentuk bentuk yang dinamis, sehingga menghasilkan poduk perhiasan yang layak untuk dipakai.

Adapun desain postmodern ini, pada produk akhir membuat 1 set perhiasan diantaranya gelang, liontin bros, cincin, dan anting-anting. Berikut rancangan desain perhiasan postmodern yang sudah melalui tahapan kelayakan oleh validato.
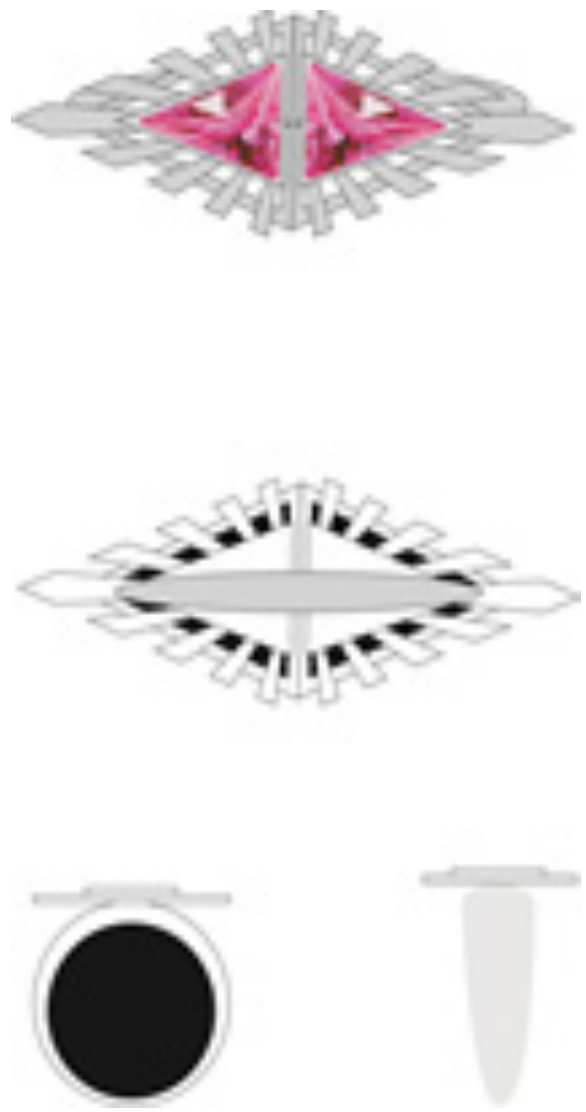

Gambar 24. Desain Gelang Surya Majapahit (Sumber: Yongky Danang Prasetyo)
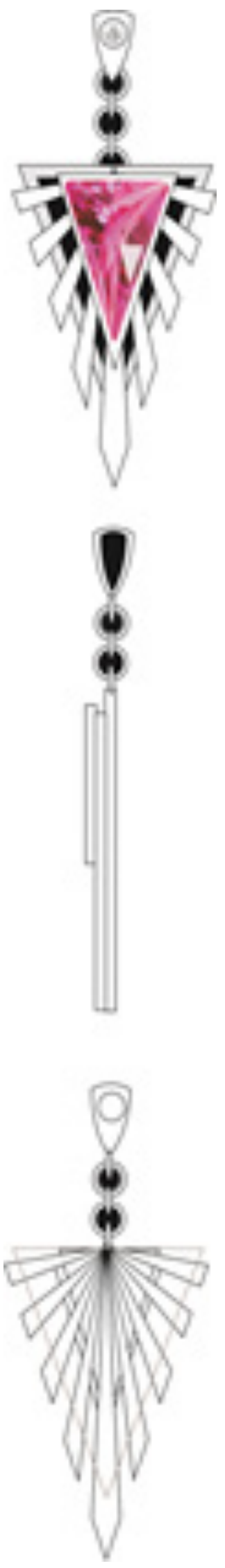

Gambar 25. Desain Liontin Surya Majapahit (Sumber: Yongky Danang Prasetyo) 

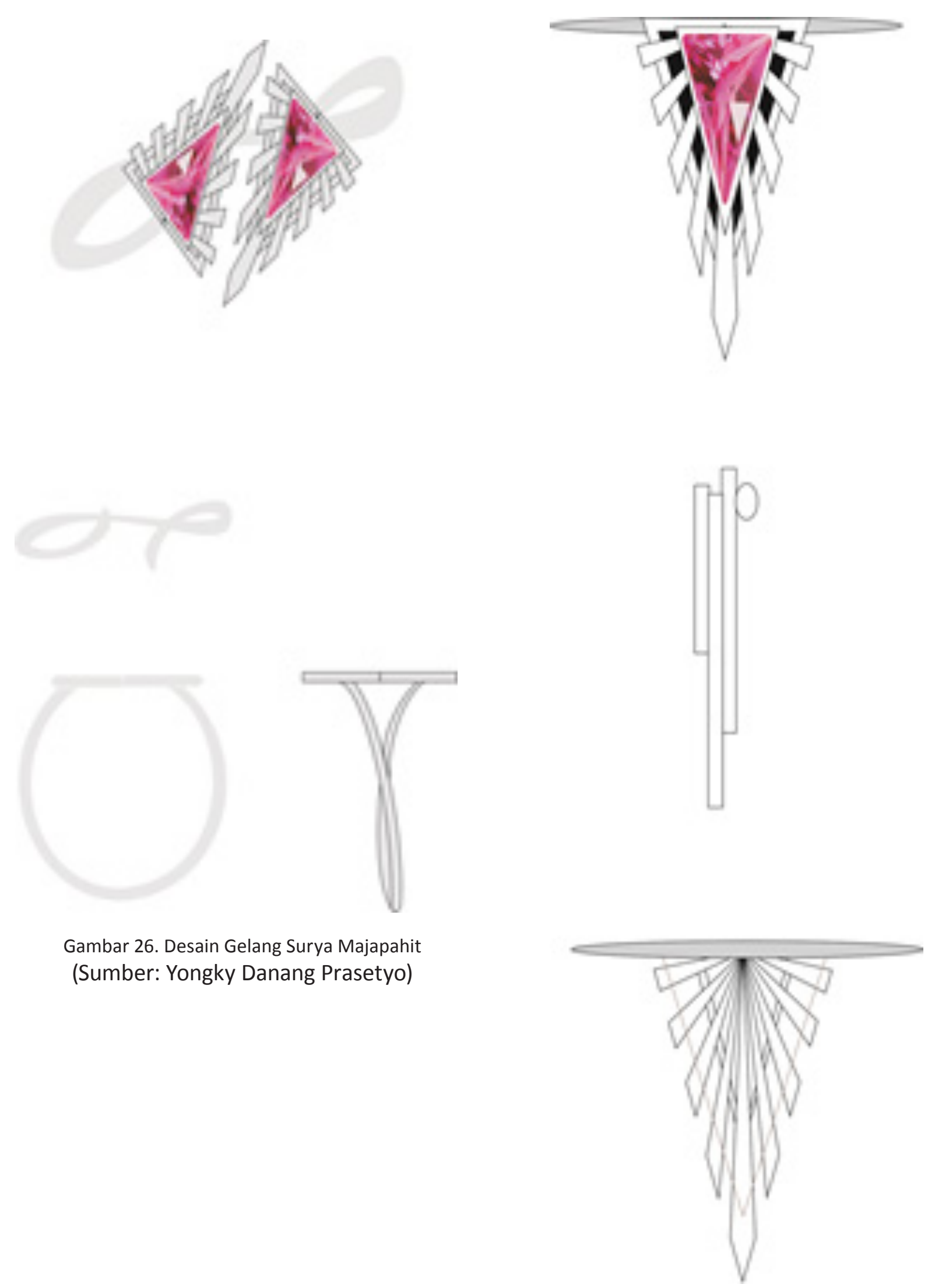

Gambar 26. Desain Gelang Surya Majapahit (Sumber: Yongky Danang Prasetyo)

Gambar 27. Desain Bros Surya Majapahit (Sumber: Yongky Danang Prasetyo) 

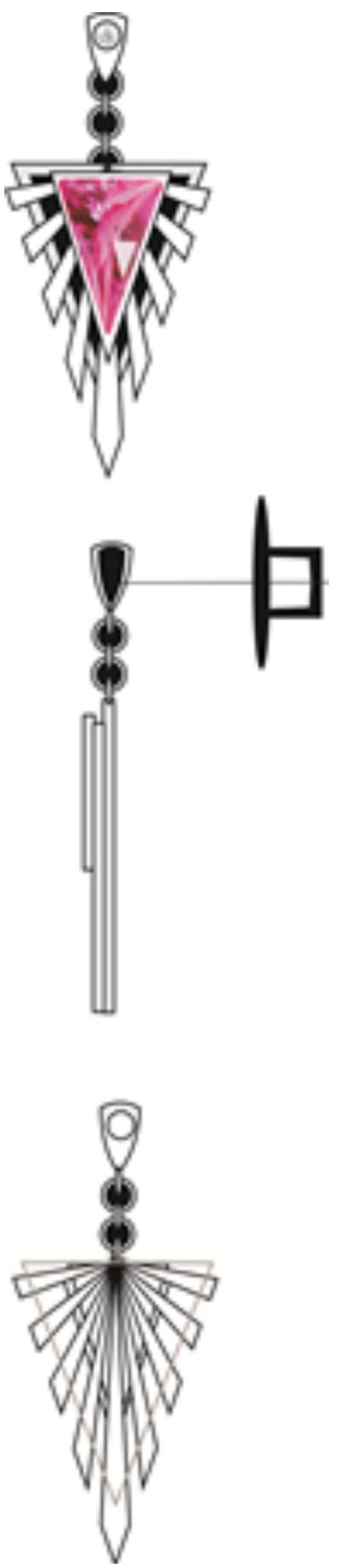

Gambar 28. Desain Anting Surya Majapahit (Sumber: Yongky Danang Prasetyo)

\section{HASIL PENELITIAN}

\section{Produk Perhiasan}

\section{Perhiasan Klasik}

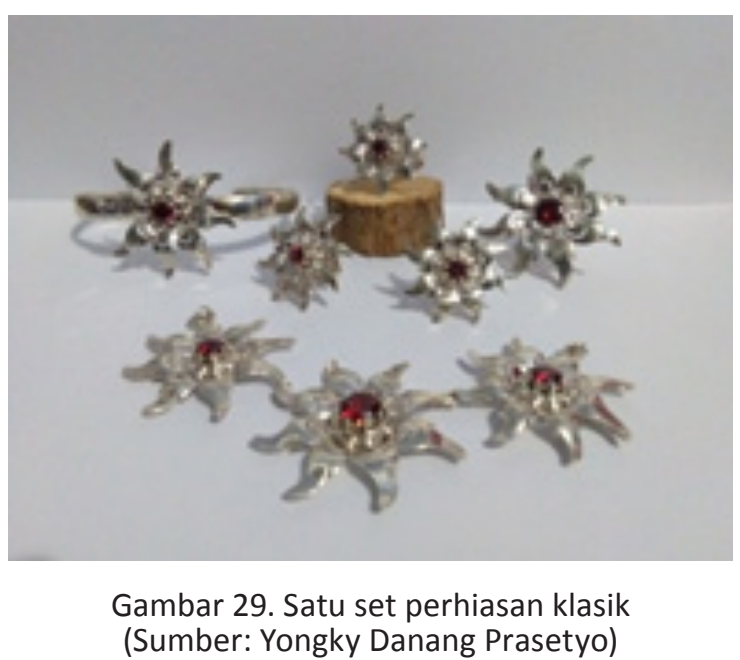

Perhiasan ini terinspirasi dari motif surya majapahit dengan menggabungkan ornament majapahit tahpan awal dalam proses produksi perhiasan peneliti melakukan observasi langsung yang kemudian mengembangkan bentuk pengamatan kedalam media dua dimensi. Surya Majapahit ini diwujudkan dalam bentuk produk liontin, cincin, gelang, anting, bros. bentuk semua item dalam produk perhiasan ini dengan mencari kemiripan, sehingga akan memunculkan nilai kesatuan jika digunakan dalam satu set perhiasan. Dalam produk perhiasan ini ditonjolkan adalah bentuk item liontin, karena bentuk liontin yang unik dengan menggabungkan 3 bentuk item yang sama sehingga dari keseluruhan item perhiasan liontin yang tampak lebih besar. Liontin terdapat beberapa teknik diantaranya teknik potong, teknik shawing, dan teknik patri. Bentuk perhiasan ini menyesuaikan bentuk ikon Surya Majapahit, dengan melihat unsur 8 sinar yang muncul dari luar lingkaran. Berat keseluruhan perhiasan yang terdiri dari bros, liontin, cincin, gelang, dan anting adalah 159 gram. Untuk mengetahui bentuk dan ukuran dari masing-masing produk dapat dijelaskan sebagai berikut: 
a. Liontin

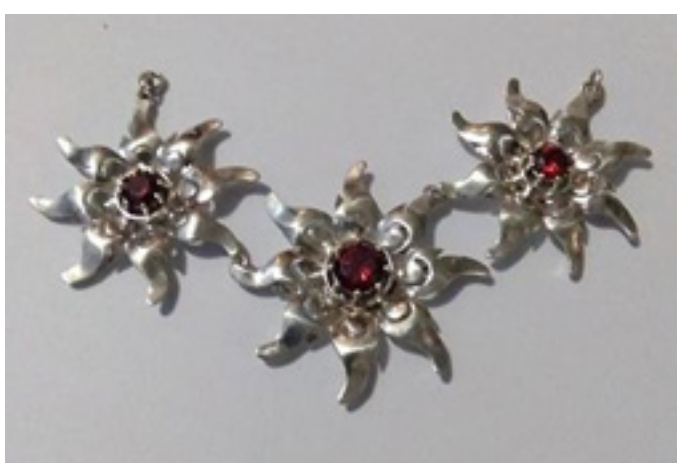

Depan

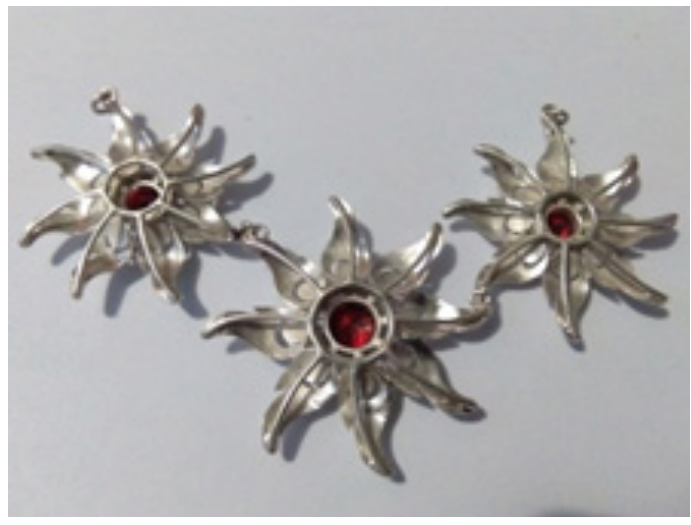

Belakang

Gambar 30. Perhiasan bentuk liontin (Sumber: Yongky Danang Prasetyo)

Produk perhiasan liontin memiliki ukuran pada bentuk A diameter $4,5 \mathrm{~cm}$, bentuk tersebut terinsirasi ornament majapahit memliki ukuran masing bentuk A panjang 1,7 $\mathrm{cm}$ dan lebar $0,7 \mathrm{~cm}$ dengan jumlah 8 bentuk ornament sebagai wujud sinar dari Surya Majapahit. Produk perhiasan ini menambahkan batu mulia garnet merah memiliki ukuran $0,9 \mathrm{~mm}$ untuk menambah estetika dan kontras pada perhiasan dengan material perak. Teknik pada penyambungan masing-masing item bentuk dengan teknik patri.sedangkan pemasangan batu dengan bentuk gigi. supaya bentuk tidak mudah lepas dari patrian disaat penyambungan penile memberikan rangka kawat pada belakang bentuk tersebut. Sedangkan bentuk B dan C memiliki diameter $3,7 \mathrm{~cm}$ dan memiliki masing-masing bentuk ornament dengan ukuran $1,4 \mathrm{~cm}$ dan lebar $0,4 \mathrm{~cm}$. ukuran untuk batu garnet merah menggunakan ukuran 0,6 $\mathrm{mm}$ dengan jumlah 2 b. Cincin

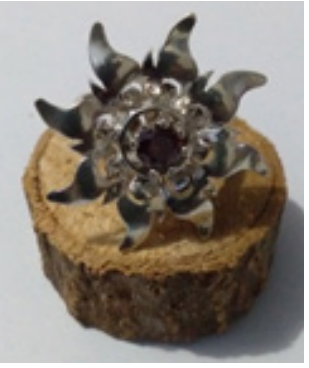

Depan

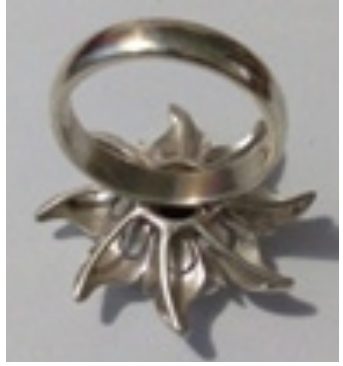

Belakang
Gambar 31. Perhiasan bentuk cincin (Sumber: Yongky Danang Prasetyo)

Produk perhiasan cincin tidak jauh beda menggunakan bentuk ornament yang sama dengan ukuran diameter $2,4 \mathrm{~cm}$. sedangkan bentuk ornament meliki panjang $1 \mathrm{~cm}$ dan lebar $0,4 \mathrm{~cm}$, dengan menggunakan batu garnet merah berukuran $0,4 \mathrm{~mm}$. Cincin ini menggunkan ring polos sigar menjalin berdiamer $1,7 \mathrm{~cm}$.

c. Gelang
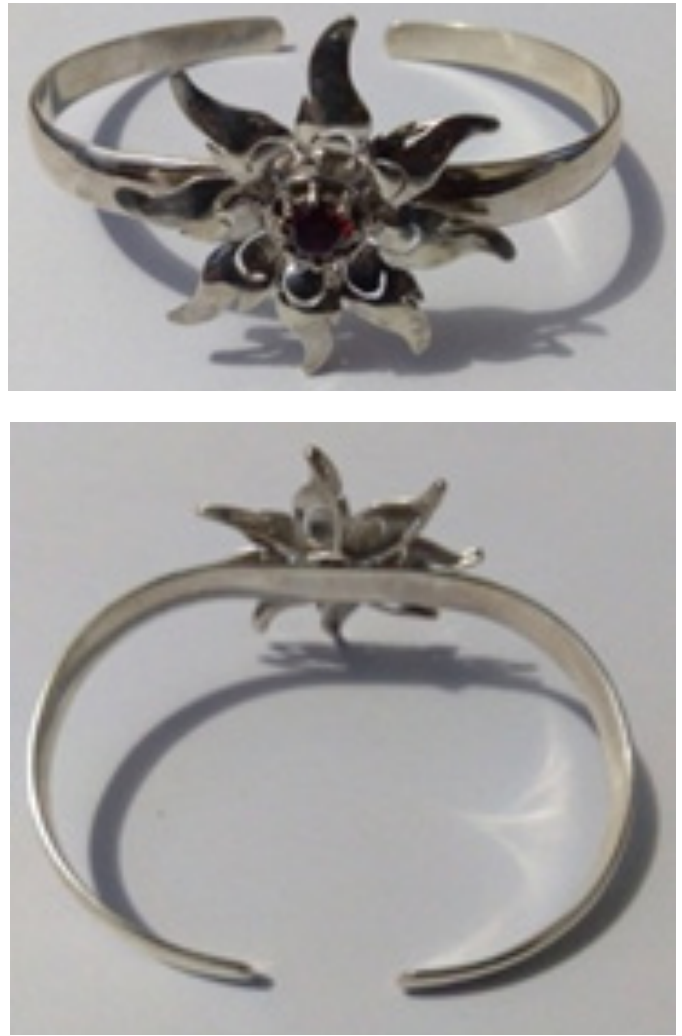

Gambar 32. Perhiasan bentuk gelang (Sumber: Yongky Danang Prasetyo) 
Pada produk perhiasan gelang bermotif Surya majapahit memiliki ukuran bentuk ber diameter $3,8 \mathrm{~cm}$ memili ukuran batu 0,6 $\mathrm{mm}$. dalam produk gelang tidak merubah bentuk, sehingga satu unsur dengan produk desain perhiasan surya majapahit sehingga menjadi satu kesatuan. Sedangkan untuk lebar pergelangan tangan memiliki ukuran panjang $6,5 \mathrm{~cm}$ dan dan tinggi $4,6 \mathrm{~cm}$, tebal plat $0,2 \mathrm{~mm}$ dan lebar $0,7 \mathrm{~mm}$ pada bagian tengah dan bawah $0,5 \mathrm{~mm}$.

d. Bros
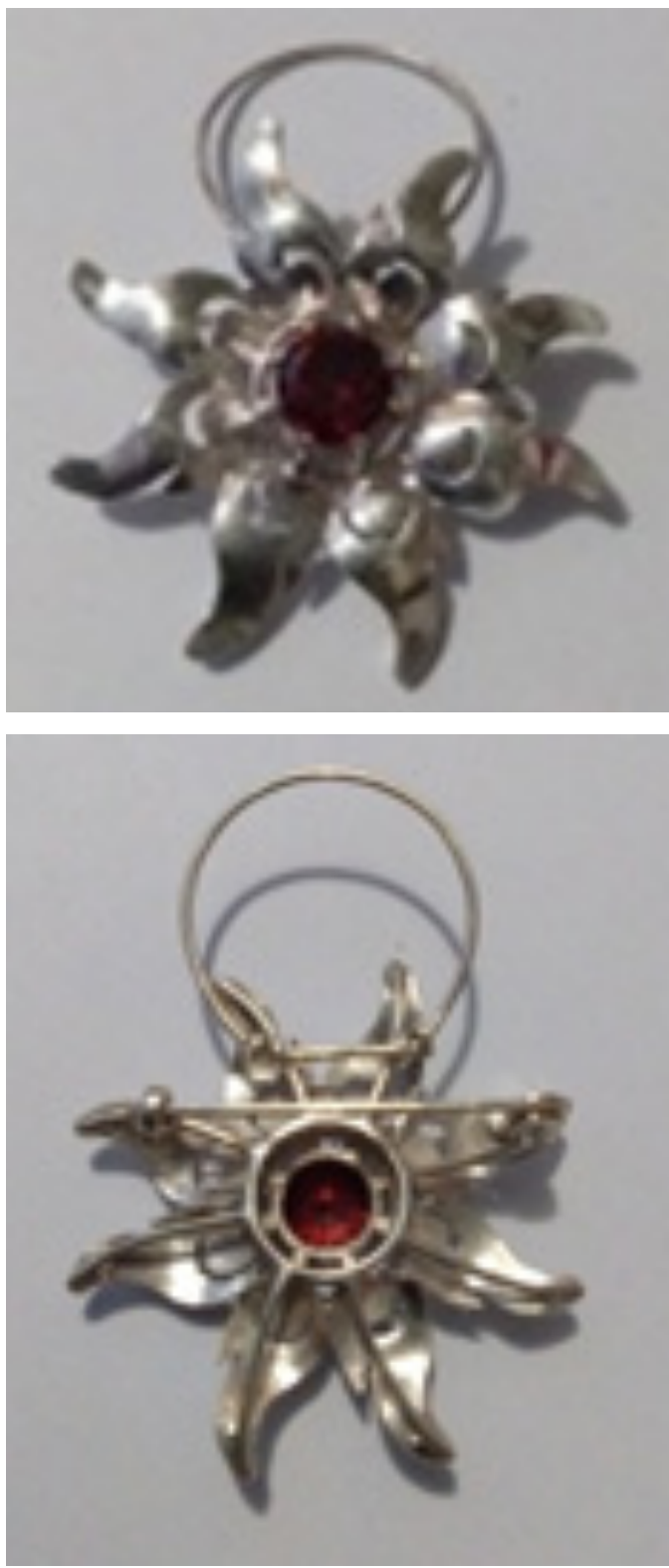

Gambar 33. Perhiasan bros (Sumber: Yongky Danang Prasetyo)
Pada produk perhiasan bros meliki ukuran bentuk ber diameter $4,2 \mathrm{~cm}$ dan menggunakan batu $0,9 \mathrm{~mm}$. pada produk perhiasan bros ini menggunakan 2 nilai fungsi digunakan dalm penggunaannya pertama untuk bros dan kedua untuk jilbab berupa ring kolong. Penggunaan ring kolong tersebut desainner berinovasi sesuai pengguna pada saat ini sebagai aksesoris untuk jilbab.

\section{e. Anting-anting}

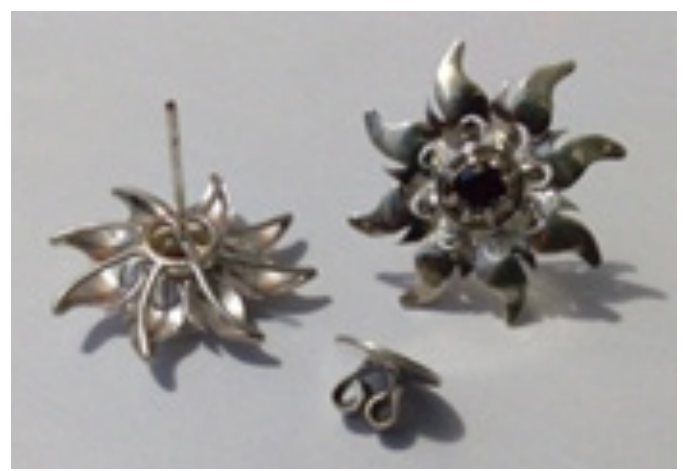

Gambar 34. Perhiasan Anting-anting (Sumber: Yongky Danang Prasetyo)

Pada produk perhiasan anting-anting desainner membuat bentuk Surya Majapahit berdiameter 2,9 $\mathrm{cm}$ dan memiliki ukuran batu $0,5 \mathrm{~mm}$. sedangkan panjang kawat untuk untuk masuk ketelinga $1,5 \mathrm{~cm}$ dan anting ini berbentuk giwangan untuk mempermudah penguna dalam segi pemakaian.

\section{Desain Postmodern Motif Surya Majapahit}

a. Gelang

Pada produk perhiasan gelang post modern ini desainner memiliki rancangan ide kreatif dengan mengambil unsur pancaran surya yang terdiri dari juraian garis keluar. Jurain tersebut tidak merubah dari konsep dan pengabilan motif dari bentuk Surya Majapahit. Juraian tersebut berbentu segitiga sama kaki, yang memiliki ukuran $1,7 \mathrm{~cm}$ dan tinggi 2,5 $\mathrm{cm}$ dan desainer meletakkan 2 bentuk juraian tersebut berbeda arah sudutnya. Sedangkan diametr pergelangan tangan untuk produk gelang berukuran panjang $6 \mathrm{~cm}$ dan tinggi $4,6 \mathrm{~cm}$. Gelang ini 
bersifat fleksibel singga dalam penggunaan produk tersebut menggambil pola Tarik sehingga mudah untuk menyesuaikan ukuran pergelangan tangan penggunanya.
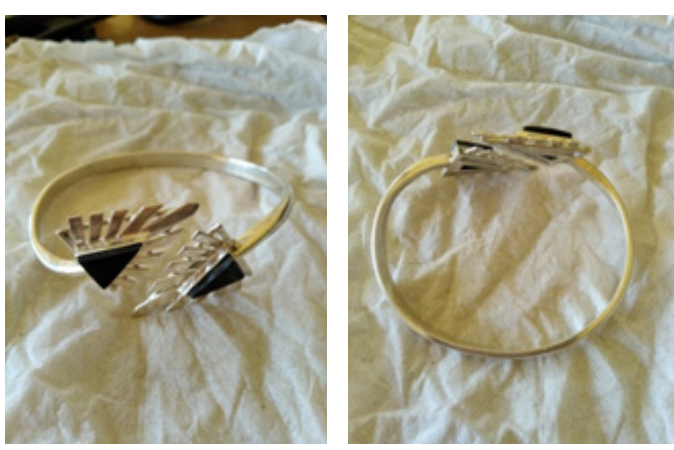

Desain Gelang

(Sumber: Yongky Danang Prasetyo)

b. Cincin

Pada produk perhiasan cincin desainer memiliki ide untuk membuat desain bentuk belah ketupat dengan juraian mengarah keluar. Bentuk belah ketupat tersebut memiliki ukururan panjang 3,5 $\mathrm{cm}$ dan lebar $2 \mathrm{~cm}$, menggunakan batu black jade berukuran panjang $1,1 \mathrm{~cm}$ dan lebar 0,6 $\mathrm{mm}$ menyesuaikan dengan bentuk kolong batunya. Sedangkan untuk ukuran besar ring menggukan ukuran diameter $1,2 \mathrm{~cm}$.

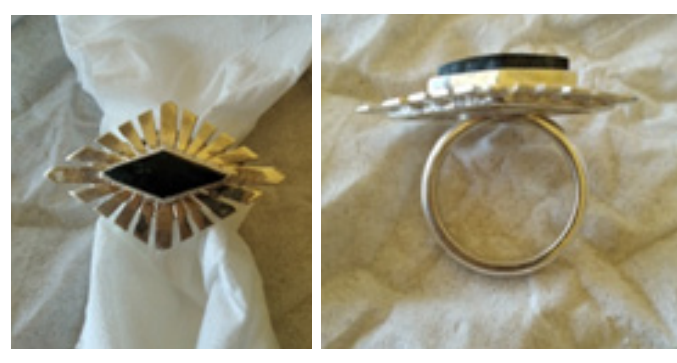

Desain Cincin

(Sumber: Yongky Danang Prasetyo)

c. Liontin

Pada bentuk produk liontin desainer tetap menggunakan juraian keluar sebagai satu kesatuan dalam tema desain Surya Majapahit. Jurain tersebut mengunkan bentuk segitiga sama kaki dengan ukuran tinggi $3,8 \mathrm{~cm}$ dan lebar $3 \mathrm{~cm}$. sedangkan diperkuat dengan kerangka kawat pada bagian bawahnya, sebagai tumpuan plat pda juraian yang mengarah keluar. Pada liontin ini deinener menggunakan rantai untuk menggabungkan antara kolong kalung dengan bentuk utama juaian surya Majapahit. Panjang ratai itu sendiri memiliki ukuran panjang $1,5 \mathrm{~cm}$, sedangkan panjang kolong liontin 1,5 $\mathrm{cm}$ dan lebar $0,5 \mathrm{~mm}$. menggunkan batu black jade panjang $2 \mathrm{~cm}$ dan lebar $1 \mathrm{~cm}$, menyesuaikan bentuk ring batu dalam liontin tersebut.

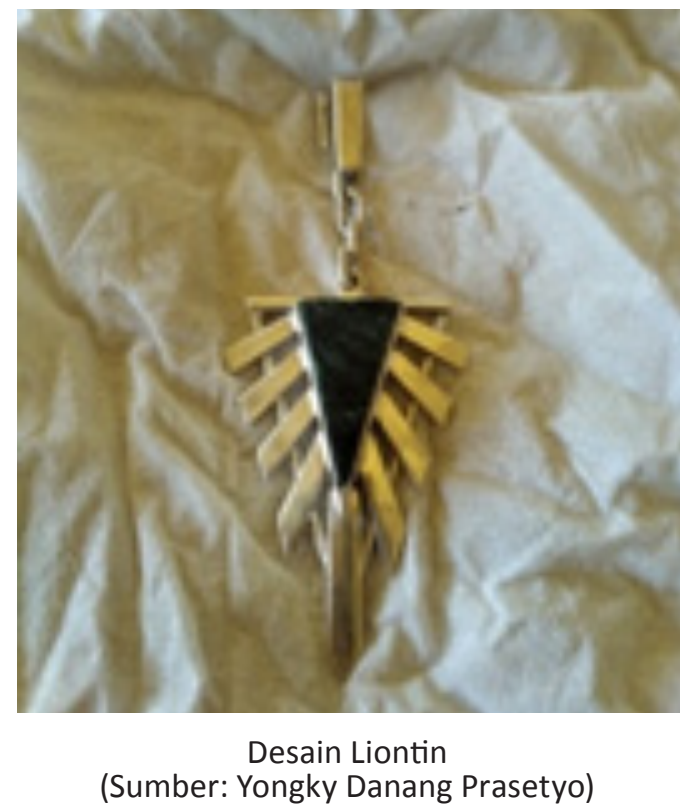

d. Bros

Dalam produk perhiasan bros desainer tetap memnggunakan juraian sebagai satu kesatuan dalam produk. Memiliki ukuran tinggi $4,5 \mathrm{~cm}$ dan lebar $3,8 \mathrm{~cm}$ dan diperkuat dengan rangka kawat pada bagian bawah plat. Sedangkan batu menggunakan black jade dengan ukuran tinggi $2,2 \mathrm{~cm}$ dan lebar $1,2 \mathrm{~cm}$. sedangkan bros ini menggunakan tusuk peniti dan kolong sebagai aksesoris pada jilbab.
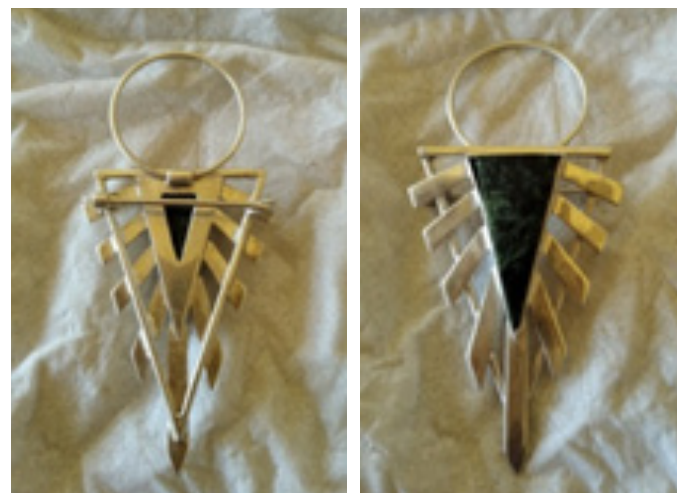

Desain Bros

(Sumber: Yongky Danang Prasetyo) 
e. Anting-anting

Pada bentuk anting-anting ini desainer tetapa menggunakan metode giwang tusuk dalam penggunaan anting-anting tersebut. Sehingga tetap memiliki unsur fleksibel dan klasik dalam desain tersebut. Anting-anting ini memiliki ukuran tinggi $2,7 \mathrm{~cm}$ dan lebar $2,2 \mathrm{~cm}$, memiliki ukuran batu black jade panjang $1,2 \mathrm{~cm}$ dan lebar $0,7 \mathrm{~mm}$. untuk menggabungkan penjepit dan bentuk juraian Surya Mjapahit desainer menggunakan rantai dengan panjang $0,8 \mathrm{~mm}$.

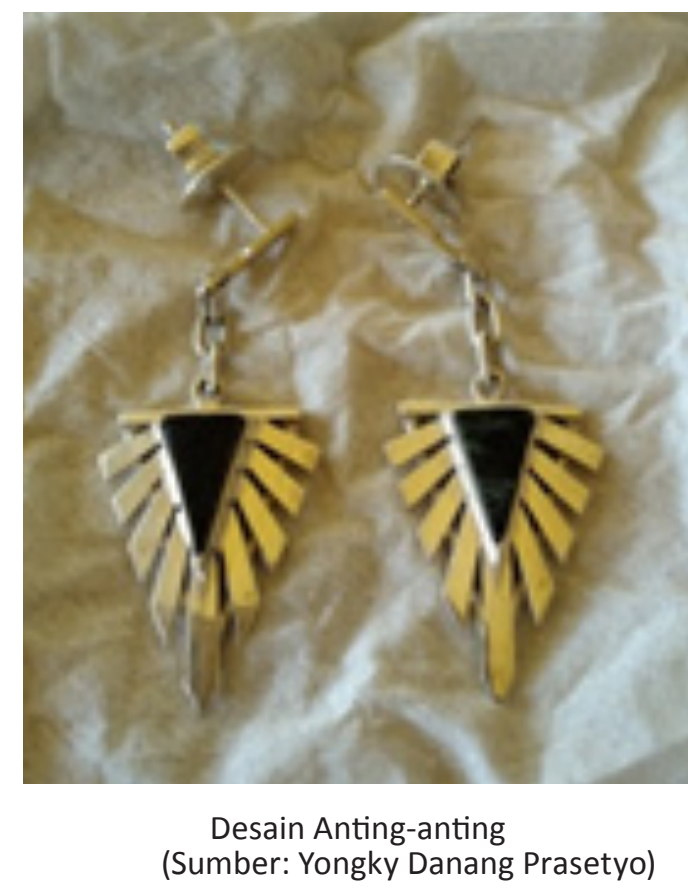

\section{Kesimpulan}

Dalam mengembangkan perhiasan motif Majapahit untuk pengrajin desa Batan Krajan kab Mojokerto Jawa Timur memperoleh kesimpulan bahwa: Dalam proses mengembangkan pehiasan ini menggunakan teori design thinking dengan enam tahapan lebih mudah dalam mengkonsep dari ide- ide, sehingga dalam perwujudannya lebih terukur dan terperinci. Keenam tahapan tersebut meliputi eksplorasi, identifikasi, idea, visualisasi, evaluasi, dan persuasi. Dengan menggunakan teori design thinking, peneliti menambahkan teori sebagai pendukung teori tersebut yaitu teori ikonografi dan teori estetika ergonomi.

Teori pendukung tersebut di gunakan karena desain yang dikembangkan adalah desain perhiasan termasuk dalam seni kriya terapan.
Sehingga menunjukkan makna dari pengambilan konsep dan segi kenyamanan pengguna. Penelitian ini menggembangkan produk kriya logam perhiasan bermotif majapahit dengan mengambil lambang Surya Majapahit. Surya Majapahit adalah lambang atau simbul kebesaran kerajaan Majapahit dengan mengambil pendekatan symbol dewata nawasanga yang berkembang di Bali. Dengan bentuk visualnya pada tengah terdapat lingkaran yang disampingnya terdapat jurai-jurai menyerupai sinar dan terdapat 9 tokoh dewa di dalamnya.

Penelitaian ini proses pengembangan produk perhiasan mengalami beberapa hambatan diantaranya waktu dan biaya produksi, sehingga dalam proses produksi mengalami keterlambatan. Dari beberapa pengrajin dengan melihat proses pengembangan perhiasan sangat terbantu dan berusaha untuk mencari alternatif untuk menunjukkan kualitas perhiasan yang sempurna. Pengembangan desain sangat penting dalam kompetisi di dunia perhiasan, sehingga pengrajin lebih aktif untuk mencari informasi tentang teknologi yang berkembang saat ini.

Dengan adanya penelitian pengembangan perhiasan ini pengrajin lebih mudah untuk mencari sumber ide kreatif dari peninggalan Kerajaan Majapahit. Menggali sumber ide inilah yang nantinya akan menjadikan cirikhas dari masing-masing pengrajin perhiasan.

\section{Saran}

Saran yang didapat dalam penelitian pengembangan perhiasan ini adalah: Peneliti dapat mengembangkan desain lebih banyak dengan motif Majapahit, karena begitu banyak peninggalan Majapahit yang perlu di eksplor lagi. Peneliti mengembangkan desain lebih banyak lagi untuk mengembangkan dengan melihat teknologi yang berkembang saat ini. Bagi pengrajin dapat mengembangkan potensi dalam mengembangkan perhiasan dengan melihat peninggalan Majapahit.

Pengrajin lebih aktif dalam mencari ilmu pengetahuan tentang perhiasan dimana kompetisi dunia perhiasan sangat tingggi. Untuk pengrajin lebih kreatif untuk mengembangkan produk perhiasan yang berkualitas. Pengrajin lebih banyak referensi untuk mengembangkan proses produksi perhiasan motif Majapahit. 


\section{Daftar Pustaka}

Berger, Arthur Asa. (2010). Pengantar Semiotika: Tanda-Tanda Dalam Kebudayaan Kontemporer. Yogyakarta: Tiara Wacana.

Creswell, John W. (2013). Penelitian Kualitatif Dan Desain Riset: Memilih Diantara Pendekatan. Yogyakarta: Pustaka Belajar.

Gustami, SP. (2007). Butir-butir Mutiara Estetika Timur. Yogyakarta: Prasista.

Haryono, T. (1991-1992). Logam Emas: Fungsi Dan Maknanya Dalam Masyarakat Jawa Kuno Abad VII-XV. Laporan Penelitian. Yogyakarta: Universitas Gadjah Mada.

Haryono, T. (1993). Seni Majapahit Dalam Kartodirjo, Sartono. Dkk. 700 Tahun Majapahit Bunga Rampai. Surabaya: Dinas Pariwisata Daerah Provinsi Tingat Jawa Timur.

Indrianti, K. (2016). Kajian Perhiasan Tradisional. E-Jurnal: Seni Dan Kria, Vol 1. (1): 3-4.

Kartika, D. S. (2004). Seni Rupa Modern. Bandung: Rekayasa Sains.

Laksana, Deddy. A. W. (2012). Desain Identitas Perusahaan. Bahan ajar

Lodra, I. N. (2012). Kriya Tradisional Dalam Cengraman Kapitalis. Bali: Sari Khayangan Indonesia

Merdiana, Reyna. (2015). Pengembangan Desain Perhiasan Wanita Berkarakter Jawa Timur Berbahan Sterling Silver Dan Menggunakan Ragam Paduan Batuan Pacitan. Surabaya: Desain Produk Industri FTSP -ITS.

Ningtyas Arum S. (2015). Sebuah Penciptaan Perhiasan Kontemporer Sebagai Karya Seni Kriya Logam. Yogyakarta: Institut Seni Indonesia.

Nugraha R. (2016). Kajian Perhiasan Tutola Jewery dengan Inspirasi Budaya Bali. Bandung: Universitas Telkom.

Panofsky, Erwin. (19550 . Meaning of The Visual Arts. New York: Doubleday Anchor Books.

Rohidi, Tjetjep R. (2011). Metodologi Penelitian Seni. Semarang: Cipta Prima Nusantara.

Sachari, Agus. (1986). Desain Gaya Dan Realita. Jakarta: Rajawali.

Sugiharto, B. (2004). Sosiologi Postmodernisme. Yogyakarta: Kanisius.
Sugiyono. (2009). Metode Penelitian Pendidikan Pendekatan Kuantitatif, Kualitatif, dan R \& D. Bandung : Alfabeta.

Supriyadiyanto. (2017). Angsa Sebagai Inspirasi Penciptaan Perhiasan Kriya Logam. Yogyakarta: Universitas Negeri Yogyakarta.

Zulizti. (2014). Ikonografi Karya Sudjojono "Di Depan Kelamboe Terboeka”. Yogyakarta: Institut Seni Indonesia Yogyakarta. 